\title{
Edge-of-Field Technologies for Phosphorus Retention from Agricultural Drainage Discharge
}

\author{
Lipe Renato Dantas Mendes (i) \\ Independent Researcher, Natal 59064-740, Brazil; liperenato@hotmail.com; \\ Tel.: +55-84-99891-8045 or +45-2336-5942
}

Received: 27 November 2019; Accepted: 1 January 2020; Published: 16 January 2020

Featured Application: This review provides a background that helps targeting the phosphorus loads from specific tile-drained agricultural catchments with suitable edge-of-field technologies, ultimately contributing to a better cost-efficiency.

\begin{abstract}
Agriculture is often responsible for the eutrophication of surface waters due to the loss of phosphorus-a normally limiting nutrient in freshwater ecosystems. Tile-drained agricultural catchments tend to increase this problem by accelerating the transport of phosphorus through subsurface drains both in dissolved (reactive and organic phosphorus) and particulate (particle-bound phosphorus) forms. The reduction of excess phosphorus loads from agricultural catchments prior to reaching downstream surface waters is therefore necessary. Edge-of-field technologies have been investigated, developed and implemented in areas with excess phosphorus losses to receive and treat the drainage discharge, when measures at the farm-scale are not able to sufficiently reduce the loads. The implementation of these technologies shall base on the phosphorus dynamics of specific catchments (e.g., phosphorus load and dominant phosphorus form) in order to ensure that local retention goals are met. Widely accepted technologies include constructed wetlands, restored wetlands, vegetated buffer strips and filter materials. These have demonstrated a large variability in the retention of phosphorus, and results from the literature can help targeting specific catchment conditions with suitable technologies. This review provides a comprehensive analysis of the currently used edge-of-field technologies for phosphorus retention in tile-drained catchments, with great focus on performance, application and limitations.
\end{abstract}

Keywords: phosphorus load; hydraulic residence time; water flow; sedimentation; sorption; constructed wetland; restored wetland; vegetated buffer strip; filter material; iron

\section{Introduction}

Agriculture is generally the main source of phosphorus $(\mathrm{P})$ to inland and coastal waters $[1,2]$. Application of mineral fertilizers and manure in agricultural fields and the presence of excess manure in intensive livestock farming commonly result in the surplus of $P$ in the soil followed by loss $[1,3]$. This represents a problem in the long-term as $\mathrm{P}$ losses tend to increase as a result of $\mathrm{P}$ accumulation in the soil [4]. The P surplus can be transported during precipitation events through surface runoff, subsurface flow and/or erosion, eventually reaching downstream surface waters [4], where P loads exceeding a certain threshold may cause eutrophication $[5,6]$. This is particularly the case in freshwater ecosystems, where $P$ is generally the limiting nutrient $[7,8]$. The European Water Framework Directive 2000/60/EC plays an important role in this context, as it regulates the use of $\mathrm{P}$ in agriculture, helping to preserve the good ecological quality of surface waters, i.e., only a slight change in the biological community is allowed. 
Tile-draining is a widespread method used to improve agricultural production in certain areas. It can increase the crop yield and reduce annual variability, thus ensuring consistent production [9]. In addition, it decreases the P losses through surface runoff and erosion [10]. Tile drainage is particularly advantageous in catchments with fine-textured soils such as clayey soils, where subsurface flow is severely reduced and soil waterlogging is recurrent, by increasing the hydrological connectivity between agricultural fields and surface waters. On the other hand, it decreases the contact time of $\mathrm{P}$ to soil particles when water infiltrates and flows down the soil profile to the tile drains, thus minimizing $P$ sorption [11]. Therefore, tile drainage accelerates the transport of $\mathrm{P}$ and largely contributes to the overall P load [12-14], where P concentrations in the drains are often highly variable and exceeding the threshold for eutrophication in surface waters [15].

Tile-drained agricultural catchments vary in geology, climate, topography, soil type, soil test $\mathrm{P}$ concentration and agricultural practices, which all influence the amount of $P$ surplus in the soil and subsequent loss, i.e., the $\mathrm{P}$ load and dominant $\mathrm{P}$ form. Variations in the $\mathrm{P}$ load and form can be rather large not only between agricultural catchments [1], but also within the same [16]. The latter occurs as a result of seasonal and inter-annual variations in precipitation, which cause base and peak-flow events, in addition to changes that may occur in the agricultural practices (e.g., inputs of P). Thus, large $\mathrm{P}$ losses are generally observed during periods of intense precipitation [15]. These observations highlight the large spatiotemporal variation in P loss from agricultural fields [1].

Phosphorus is commonly found in agricultural soils bound to particles and oxides of iron (Fe), aluminum $(\mathrm{Al})$ and manganese as well as to calcium $(\mathrm{Ca})$ and magnesium $(\mathrm{Mg})$ [10]. However, $\mathrm{pH}$ and redox conditions regulate the sorption reactions of $\mathrm{P}$ to these elements, and consequently the proportion of soluble and insoluble inorganic P compounds $[17,18]$. Therefore, $\mathrm{P}$ loss in drainage discharge mostly occurs as inorganic compounds comprised by dissolved reactive P (DRP) and particulate or particle-bound P (PP). The load of these forms in tile drains can be similarly high [19] and is largely controlled by preferential macro-pore flow, which connects the soil surface to the drains. The loss of DRP is favored by the application of mineral fertilizers or manure followed by precipitation or snowmelt events, which cause P desorption and leaching [20-22] as a result of soil waterlogging and emergence of reducing conditions $[18,23]$. The loss of PP, in turn, depends on the loss of particles and associated $\mathrm{P}$, which occurs more frequently in fine-textured soils [24] during peak-flow events [25]. Thus, a considerable fraction of PP in tile drains may be colloidal or bound to fine size particles with low sedimentation rates [24]. In line with the above, some studies demonstrated a relationship between the losses of suspended particles and $P$ in agricultural catchments [26,27]. Finally, the varying loads and dominant forms of $\mathrm{P}$ from agricultural catchments are also attributed to differences in the $\mathrm{P}$ sorption capacity of soils, which often correlates positively and negatively to the retention of DRP and PP, respectively [15] - finer-textured soils have larger surface area for sorption reactions with P [28], but are likely to lose more particles and associated $\mathrm{P}$ to tile drains $[29,30]$.

Measures to mitigate $\mathrm{P}$ loss in drainage discharge may focus on strategies at the farm-scale or at the edge of agricultural catchments. Measures at the farm-scale mostly focus on controlling the application and management of mineral fertilizers and manure through farm policies [1] and agricultural practices [4]. The latter reflects an attempt to optimize the use of $\mathrm{P}$ by balancing the $\mathrm{P}$ inputs with crop uptake so as to approximate to the critical value, i.e., the P content in the soil where no additional $\mathrm{P}$ application is needed to promote crop growth [31]. This approach tends to minimize $P$ accumulation in the soil and subsequent loss [32]. Other practices that mitigate $P$ loss at the farm-scale include tillage, which decreases preferential flow in the soil profile [33-35]; catch crops, which support P uptake in the root zone [36]; liming, i.e., the addition of Ca compounds to the soil to enhance P retention, and incorporation of manure into the soil by mixing as opposed to broadcast application $[32,35]$; and controlled drainage, which can be used to reduce the drainage discharge and subsequent transport of $\mathrm{P}$ [37].

However, attempts to minimize the P loss at the farm-scale may be limited by the lack of short-term results in soils with large P contents [38]. A limited effect of the practices described above may occur in 
an annual basis in response to soil desiccation and freezing-thaw cycles, which recreate preferential flow in the soil profile [39,40]; no net uptake of $\mathrm{P}$ by catch crops due to the release of previously assimilated $P$ during freezing-thaw cycles [41,42]; intense precipitation events, which result in diffuse $\mathrm{P}$ losses [43]; and intensive livestock farming, with excess manure being produced [44,45]. Finally, controlled drainage may otherwise increase the loss of DRP by elevating the water table and promoting the emergence of reducing conditions with concomitant release of $\mathrm{P}$ [46].

Strategies at the level of tile drains to reduce $\mathrm{P}$ loss may include attempts to increase the P sorption capacity of the subsoils around the drains by backfilling, e.g., with gypsum filters [47], Fe-containing material [48] or industrial by-products [49]. The maintenance requirements and low P retention efficiencies under intense precipitation events, however, may make these strategies impractical at the farm-scale.

The $\mathrm{P}$ index is a process-based model which helps identifying the potential of agricultural catchments for P loss [4]. In catchments with high P index or high risk of P loss, i.e., critical source areas [50], there may be a need for additional measures to mitigate the $P$ load such as the implementation of edge-of-field technologies, which are located at the edge of agricultural catchments. These may include constructed wetlands (CWs), restored wetlands (RWs), vegetated buffer strips (VBSs) and filter materials (FMs), which are recognized as non-point and economically feasible solutions. However, these are generally more costly than measures at the farm-scale, highlighting thus the importance to identify critical source areas as a first step [51]. Despite the higher costs, these technologies may offer other environmental benefits such as nitrogen removal, increases in biodiversity and flood control [52-55]. Edge-of-field technologies function as drainage filters and are installed at the outlet of the main drainage pipe of a particular tile-drained agricultural catchment. Therein, the filters are expected to work as P sinks, where the P load would gradually decrease from the inlet to the outlet of the system through retention mechanisms deemed low cost.

However, edge-of-field technologies present large variability in P retention as discussed in the next sections, which is commonly the case for systems receiving event-driven drainage discharge. In addition, their retention performance for $\mathrm{P}$ may be favored or limited depending on the catchment characteristics, e.g., $\mathrm{P}$ load and dominant $\mathrm{P}$ form, and design. Thus, it is important that the operating capacity and lifetime of these systems are fully understood before implementation, so the problem with $\mathrm{P}$ loss can be properly targeted in different agricultural catchments. This approach would consequently improve the cost-efficiency for P retention in critical source areas and ultimately support compliance with the P retention goals at the catchment-scale and sustainable agriculture. Therefore, this review aims to (i) provide an overview of currently used edge-of-field technologies for P retention from agricultural drainage discharge, (ii) describe their applicability and limitations, (iii) discuss the $P$ retention performance and causes of variability, and (iv) suggest targeting approaches for P retention under specific catchment conditions. The review indirectly supports the use of site-specific regulations for P use at the farm-scale based on the catchment characteristics and efficiency of edge-of-field technologies, as opposed to general regulations. This would enhance the retention of $\mathrm{P}$ in critical source areas with minimal impact on the agricultural practices.

This review avoided citing studies dealing with other water runoff pathways other than agricultural drainage discharge as the effluent treated, and has no focus on P management or processes at the farm-scale. However, studies dealing with agricultural surface runoff were sometimes cited to provide complementary information or to cover the lack of studies with agricultural drainage discharge.

\section{Edge-of-Field Technologies}

The development and implementation of edge-of-field technologies occurred in response to the need to reestablish ecosystems services which were lost in the land due to the expansion of agriculture. Thus, natural processes in the land that retain $\mathrm{P}$ and consequently reduce the $\mathrm{P}$ load from agricultural areas to surface waters were lost or severely attenuated. Important ecosystems which provide these benefits include wetlands and riparian vegetation [56]. 
Wetlands are waterlogged ecosystems normally presenting seasonal variations in water level, where hydrophyte plants adapted to soil anaerobic conditions are found [57]. They receive surface and subsurface water flows from uplands and decrease the P load by sedimentation of PP, sorption of DRP to sediments, and biological uptake of bioavailable forms (e.g., orthophosphate), before the water flows downstream [58]. Riparian vegetation, in turn, consists of cover plants, shrubs and trees found between uplands and along the bank of rivers and streams. This ecosystem intercepts the water flow from uplands, lowering the P load in the root zone by plant uptake and entrapment of PP before it reaches the waterways [59].

Agricultural drainage was largely responsible for the loss of these ecosystems by reducing the water storage of the land and increasing the water flow to waterways [60,61]. This consequently lowered local water tables and resulted in the conversion of wetlands to agricultural fields. The disruption of the hydrological regime at riparian floodplains affected the riparian vegetation, which has also been lost owing to deforestation for expansion of croplands and livestock grazing [62]. Furthermore, the natural buffer capacity of soils to sorb and retain $\mathrm{P}$ has been affected in agricultural catchments by the increasing levels of $P$ saturation in response to the widespread use of mineral fertilizers and manure [63-65].

The loss of these ecosystems and lower soil retention capacity for $\mathrm{P}$, in addition to the increase in $\mathrm{P}$ transport through tile drains, resulted in a decreasing capacity of the land to retain $\mathrm{P}$ and prevent eutrophication in surface waters $[56,60]$. Therefore, edge-of-field technologies have been implemented in agricultural catchments to replicate some of the natural retention processes and serve as low cost mitigation options.

\subsection{Constructed Wetlands}

Constructed wetlands are systems designed to copy the nutrient reduction processes of natural wetlands. They have a broad application, extending to the treatment of wastewater of different sources [66]. In tile-drained agricultural catchments, they are commonly constructed at the outlet of the main discharge pipe. The retention of $\mathrm{P}$ occurs through physical, chemical and biological processes mediated by the interaction of different $\mathrm{P}$ pools, i.e., plants, macro and microorganisms, sediments, soil and water. A net $\mathrm{P}$ retention consequently results in the reduction of the water $\mathrm{P}$ pool while flowing through the system. Constructed wetlands are classified as surface-flow or subsurface-flow systems depending on whether the water flows over or under the soil surface.

The performance of CWs is dependent on the operational parameters regulated by the catchment characteristics, e.g., $\mathrm{P}$ load and dominant $\mathrm{P}$ form, and the $\mathrm{CW}$ design, which influences the hydraulic residence time (HRT) and hydraulic efficiency of the CW [67]. These parameters normally show a large degree of variation seasonally and annually, which leads to the large variability in P retention between CWs. This consequently makes the retention performance difficult to predict.

Generally, the studies demonstrate that surface-flow constructed wetlands (SFCWs) work as P sinks [68-74], while some studies indicate that these can also be $P$ sources $[52,54,75,76]$ when receiving event-driven agricultural drainage discharge. Moreover, surface-flow wetlands constructed in former agricultural lands may initially be $\mathrm{P}$ sources due to the accumulation of $\mathrm{P}$ from previous agricultural practices [77]. When assessing the compilation of these studies, however, it is clear that the inter-annual variation in mass and percentage P retention between SFCWs can be considerable (Figure 1). 

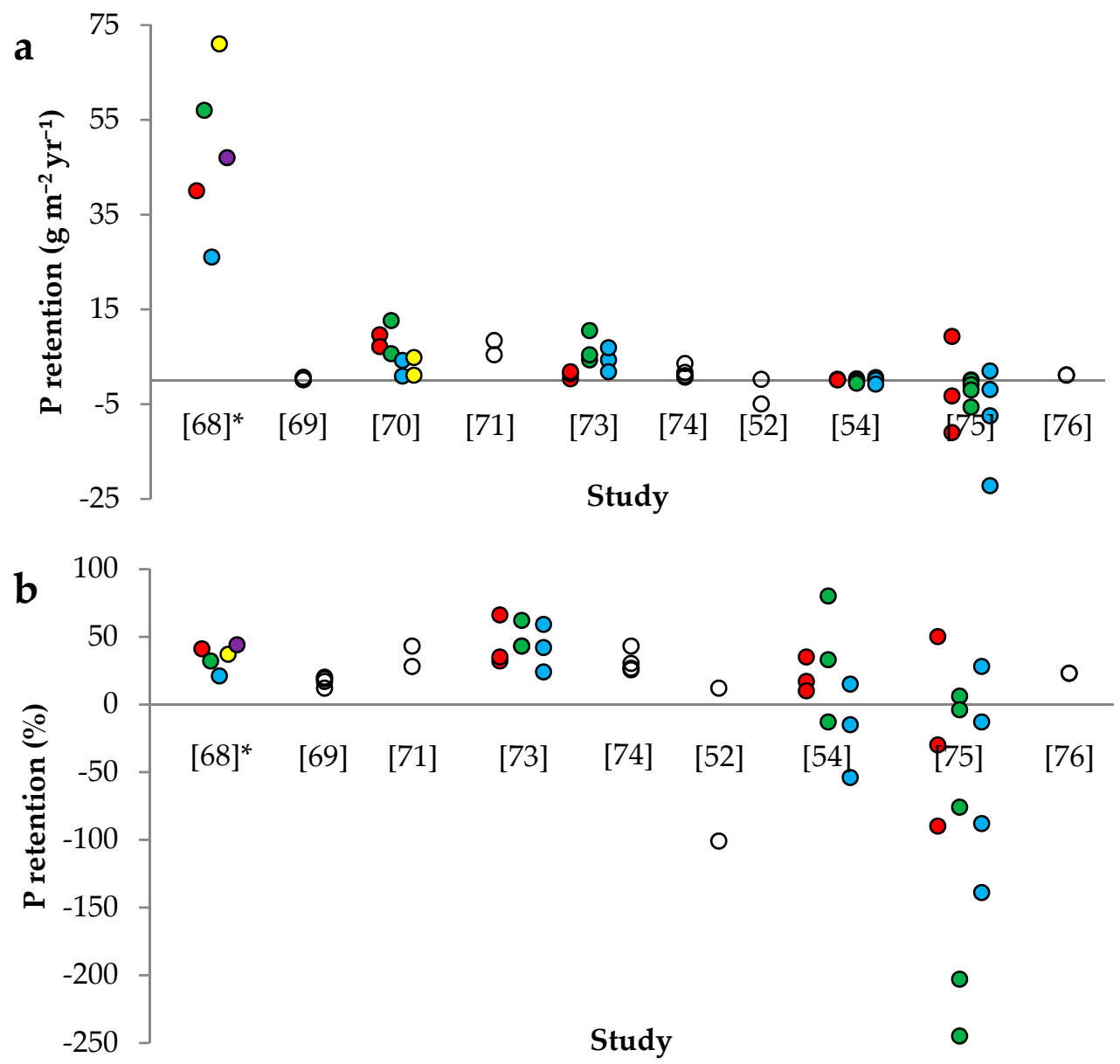

Figure 1. Inter-annual variation in mass (a) and percentage $(\mathbf{b})$ phosphorus $(\mathrm{P})$ retention in surfaceflow constructed wetlands receiving agricultural drainage discharge from 10 reference studies. Different colors in the same study indicate different wetlands. Negative values indicate net P export.

* Average values.

The variability in P retention between CWs is caused by hydrochemical, hydrological and biogeochemical factors which are controlled by the catchment characteristics and $\mathrm{CW}$ design.

The P load (Equation (1)) correlates positively to the mass P retention (Equation (2)) and is normally a large explanatory variable $[68,71,73]$. This suggests that higher mass $P$ retention is likely found under increasing $\mathrm{P}$ loads, as the $\mathrm{P}$ retention mechanisms are dependent on the inputs of $\mathrm{P}$. DeBusk et al. [78] demonstrated that P load can be rather variable between SFCWs (as also observed in Table 1) and indeed a strong factor regulating the mass $P$ retention.

$$
\begin{gathered}
\mathrm{P} \text { load }=\frac{\text { water flow }\left(\mathrm{m}^{3} \mathrm{yr}^{-1}\right) \times \mathrm{P} \text { concentration }\left(\mathrm{g} \mathrm{m}^{-3}\right)}{\text { wetland area }\left(\mathrm{m}^{2}\right)} \\
\text { mass } \mathrm{P} \text { retention }=\mathrm{P} \text { load }\left(\mathrm{g} \mathrm{m}^{-2} \mathrm{yr}^{-1}\right)-\mathrm{P} \text { load at the outlet }\left(\mathrm{g} \mathrm{m}^{-2} \mathrm{yr}^{-1}\right)
\end{gathered}
$$

The retention of $\mathrm{P}$ in SFCWs occurs through a number of processes and mainly includes sedimentation of PP forming a layer of deposited material on the soil surface; sorption of DRP to reactive sites in the soil; precipitation of DRP with oxides of $\mathrm{Fe}$ and $\mathrm{Al}$, and $\mathrm{Ca}$ in the water column to the top sediments; and biological uptake by plants, phytoplankton and bacteria of bioavailable forms [79] (Figure 2). As the different retention mechanisms carry out the retention of different $\mathrm{P}$ forms, the overall mass retention varies depending on the dominant $\mathrm{P}$ form at the incoming $\mathrm{P}$ load. Therefore, 
it is important to assess the efficiency of different $\mathrm{P}$ retention mechanisms when estimating the mass retention of $\mathrm{P}$ in SFCWs.

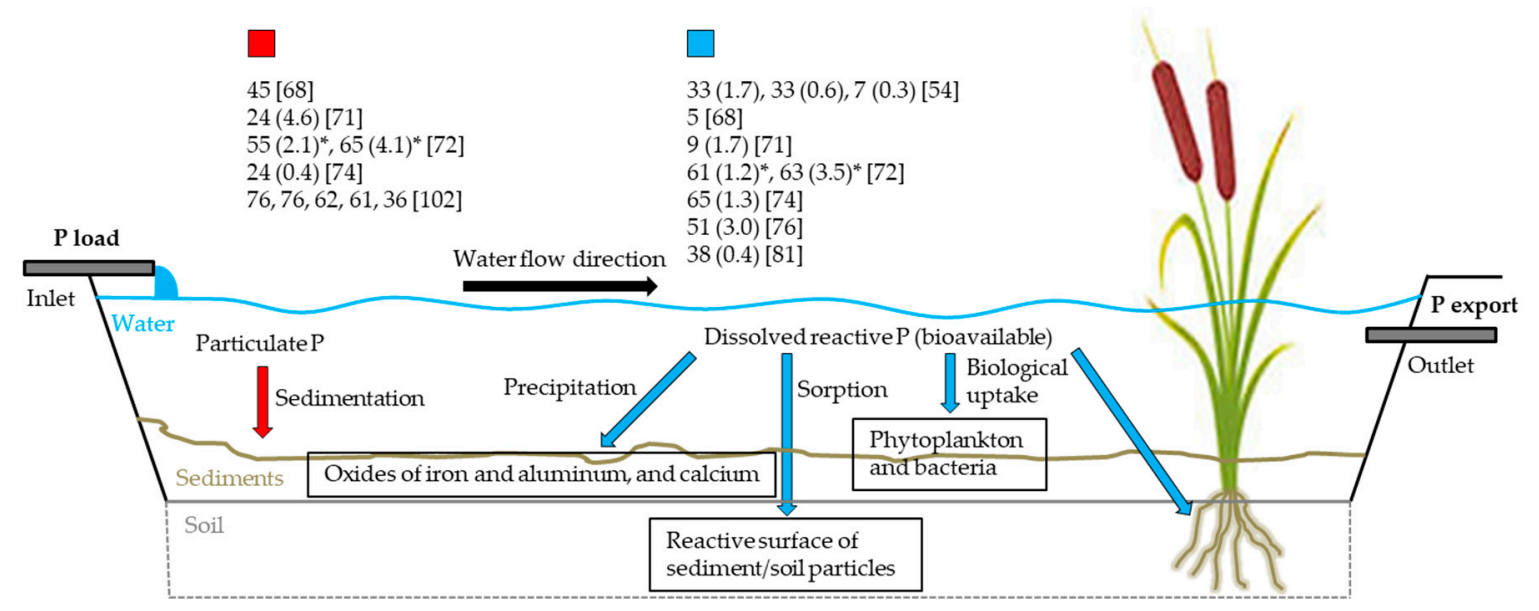

Figure 2. Schematic of the retention mechanisms of phosphorus $(\mathrm{P})$ in a surface-flow constructed wetland receiving agricultural drainage discharge. The numbers indicate the percentage and mass ( $\mathrm{g} \mathrm{m}^{-2} \mathrm{yr}^{-1}$ within brackets) retention of particulate and dissolved reactive $\mathrm{P}$ loads (red and blue box, respectively) in different systems and are followed by the reference study (within square brackets).

*Values in $\mathrm{g} \mathrm{m}^{-2}$ season $^{-1}$.

Surface-flow constructed wetlands are widely known as sinks of PP due to sedimentation of suspended particles and organic material [76,79]. Thus, the accretion of deposited material at the bottom forming a sediment layer constitutes the main retention mechanism, which is generally the case for most of the $\mathrm{P}$ retained $[69,70,80]$. Thereby, the pool of $\mathrm{P}$ in the sediments is generally the largest and represents a long-term retention. The uptake rate of bioavailable forms of $\mathrm{P}$ by plants increases during the growing season [81]. It is, however, normally low compared to other retention mechanisms and the contribution to the overall retention can be limited [81], unless the P load to the SFCW is low [82]. Emergent plant species (e.g., Typha latifolia, Phragmites australis and Juncus effusus), however, may be recommended in the retention of dissolved reactive and organic P in SFCWs under higher $P$ loads [82-84]. Nevertheless, the retention of $\mathrm{P}$ by plants and microorganisms represents a small fraction due to seasonal turnover, which includes the accumulation of organic particles at the bottom during the senescence period followed by mineralization and release of dissolved reactive and organic $\mathrm{P}[85,86]$ (Figure 3). Therefore, the $\mathrm{P}$ pool in the plants and other organisms is considered short-term. A small fraction, however, is retained in the long-term as refractory organic $\mathrm{P}$, which contributes to new soil material [79] (Figure 3).

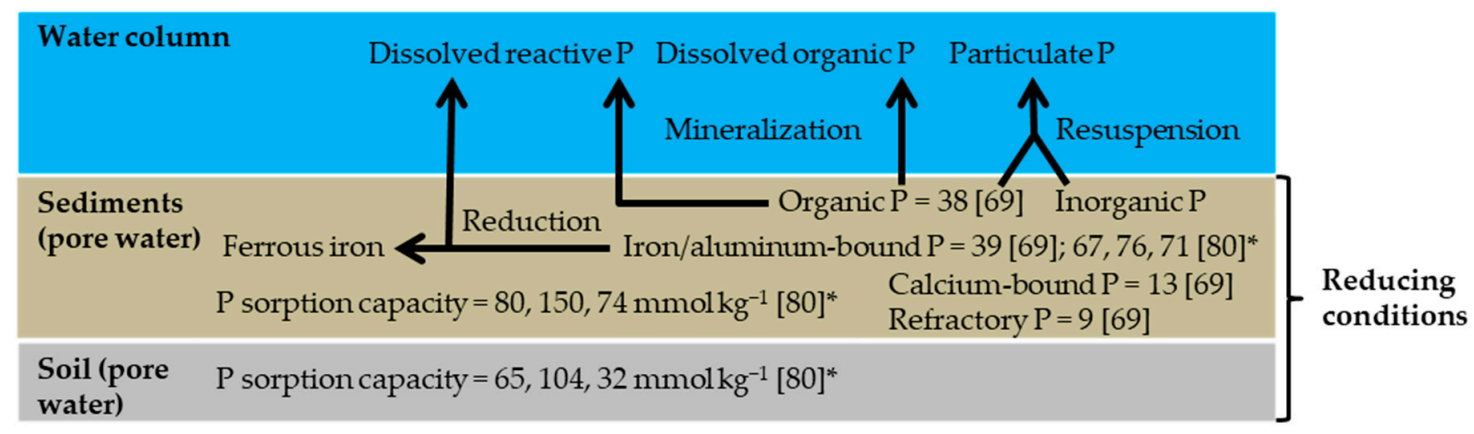

Figure 3. Schematic of the release processes of phosphorus $(\mathrm{P})$ from the sediments to the water column in a surface-flow constructed wetland receiving agricultural drainage discharge. The numbers indicate the fraction of total P (\%) and are followed by the reference study (within square brackets). * Average values for individual wetlands. 
The stability of DRP retained by chemical interactions with P sorption sites at the soil is variable and depends on the geochemical characteristics, $\mathrm{pH}$ and redox conditions as well as on the concentration gradient across the soil-water interface $[80,87,88]$. This way, DRP can be released under certain conditions, including low sorption capacity of the soil, non-neutral $\mathrm{pH}$, reducing conditions (Figure 3) and low $\mathrm{P}$ concentration in the overlying water. The observations above suggest that PP is more easily retained and stored in SFCWs than DRP. Therefore, the overall mass retention of P may increase under higher fractions of PP from the total P in the incoming $\mathrm{P}$ load due to higher efficiency of the related retention mechanisms (as suggested by the data in Figure 2). Mendes et al. [73], for example, demonstrated that mass $P$ retention increased more promptly under higher P loads in SFCWs receiving $\mathrm{PP}$ as the dominant fraction. Moreover, Johannesson et al. [69] found that 78\% of the P load, comprised mostly by PP ( $69 \%$, Table 1$)$, had been retained in the inlet zone by sedimentation forming a layer of accumulated material. Finally, Braskerud et al. [89] reported from annual data of 16 SFCWs receiving either agricultural runoff or drainage discharge that the ratio of DRP to total $\mathrm{P}$ correlated negatively not only with mass $P$ retention $(r=-0.63)$ but also with percentage $P$ retention $(r=-0.39)$. However, factors such as the particle size and density as well as the vegetation cover, which mitigates sediments resuspension, influence the sedimentation velocity and retention of particles and associated $\mathrm{P}$, as seen for SFCWs receiving agricultural runoff [90,91]. Ulén [24], for example, indicated that retention of $P$ associated to colloids and fine size particles in SFCWs can be difficult due to low sedimentation rates $\left(<1 \mathrm{~cm} \mathrm{~d}^{-1}\right)$. The above highlights the importance of dominant $\mathrm{P}$ forms in the $\mathrm{P}$ load to estimate the retention potential.

Table 1. Average annual hydraulic and phosphorus $(\mathrm{P})$ load as well as mass $\mathrm{P}$ retention of surface-flow constructed wetlands (SFCWs) receiving agricultural drainage discharge investigated in different studies. Included are the SFCW areas $\left(\mathrm{A}_{\mathrm{SFCW}}\right)$ and their ratios to the agricultural catchment areas $\left(\mathrm{A}_{\mathrm{AC}}\right)$ as well as the average $\mathrm{P}$ concentration, incoming fractions of dissolved reactive and organic $\mathrm{P}$ (DP) and particulate $\mathrm{P}$ (PP) from total $\mathrm{P}$, nominal hydraulic residence time and percentage $\mathrm{P}$ retention for the entire monitoring period.

\begin{tabular}{|c|c|c|c|c|c|c|c|c|c|c|c|c|}
\hline \multirow[t]{2}{*}{ Country } & \multirow[t]{2}{*}{ Name } & \multirow{2}{*}{$\frac{\mathrm{A}_{\mathrm{SFCW}}}{\mathrm{m}^{2}}$} & \multirow{2}{*}{$\begin{array}{c}\begin{array}{c}\text { Ratio of } \\
\text { A }_{\mathrm{SFCW}} \\
\text { to } \mathbf{A}_{\mathrm{AC}}\end{array} \\
\%\end{array}$} & \multirow{2}{*}{$\begin{array}{c}\begin{array}{c}\text { Monitoring } \\
\text { Time }\end{array} \\
\mathrm{yr}\end{array}$} & \multirow{2}{*}{$\begin{array}{c}\begin{array}{c}\text { Hydraulic } \\
\text { Load }\end{array} \\
\mathrm{m} \mathrm{yr}^{-1}\end{array}$} & \multirow{2}{*}{$\begin{array}{c}\mathbf{P} \\
\text { Concentration } \\
\mathrm{mg} \mathrm{L}^{-1}\end{array}$} & \multirow{2}{*}{$\begin{array}{c}\text { P Load } \\
\begin{array}{c}\mathrm{g} \mathrm{m}^{-2} \\
\mathrm{yr}^{-1}\end{array} \\
\end{array}$} & \multirow{2}{*}{$\begin{array}{c}\begin{array}{c}\text { DP/PP } \\
\text { Fraction }\end{array} \\
\%\end{array}$} & \multirow{2}{*}{$\begin{array}{c}\begin{array}{c}\text { Hydraulic } \\
\text { Residence } \\
\text { Time }\end{array} \\
\text { d }\end{array}$} & \multicolumn{2}{|c|}{ P Retention } & \multirow[t]{2}{*}{ Study } \\
\hline & & & & & & & & & & $\begin{array}{c}\mathrm{g} \mathrm{m}^{-2} \\
\mathrm{yr}^{-1}\end{array}$ & $\%$ & \\
\hline Norway & Berg & 900 & 0.06 & 7 & 595 & 0.17 & 97 & - & - & 40 & 41 & [68] \\
\hline Norway & Kinn & 345 & 0.07 & 7 & 661 & 0.25 & 178 & $12 / 88$ & - & 57 & 32 & [68] \\
\hline Norway & Flatabekken & 870 & 0.08 & 4 & 588 & 0.22 & 124 & $49 / 51$ & - & 26 & 21 & [68] \\
\hline Norway & Grautholen 1 & 460 & 0.21 & 3 & 445 & 0.43 & 191 & - & - & 71 & 37 & [68] \\
\hline Norway & Grautholen 2 & 840 & 0.38 & 3 & 241 & 0.43 & 106 & - & - & 47 & 44 & [68] \\
\hline Sweden & Södra Stene & 21,000 & 2.2 & 4 & 6.7 & $0.13^{\mathrm{a}}$ & 1.62 & $31 / 69$ & - & 0.27 & 16 & [69] \\
\hline Sweden & Bergaholm & 800 & 0.3 & 2 & 60 & 0.30 & 19 & $33 / 67$ & $7^{b}$ & 6.9 & 36 & [71] \\
\hline Denmark & Rodstenseje & 8950 & 1.1 & 3 & 17 & $0.18^{c}$ & 2.80 & $60 / 40^{\mathrm{d}}$ & 20 & 1.2 & 42 & [73] \\
\hline Denmark & Ryaa 1 & 21,190 & 0.9 & 3 & 60 & $0.21^{c}$ & 14 & $46 / 54^{\mathrm{d}}$ & 4 & 6.7 & 51 & [73] \\
\hline Denmark & Ryaa 3 & 8480 & 1.1 & 3 & 32 & $0.22^{c}$ & 11 & $46 / 50^{\mathrm{d}}$ & 9 & 4.3 & 41 & [73] \\
\hline Canada & Walbridge & 1215 & $0.004^{\mathrm{e}}$ & 4 & 107 & 0.08 & 5.02 & $65 / 35$ & - & 1.7 & 34 & [74] \\
\hline New Zealand & Toenepi & 260 & 1 & 2 & 25 & $0.1-0.2^{\mathrm{f}}$ & 3.17 & $92 \mathrm{~g}$ & $4^{\mathrm{h}}$ & -2.4 & -76 & [52] \\
\hline USA & Wetland A & 6000 & 4 & 3 & 8.0 & 0.21 & 1.67 & $100 / 0$ & 41 & 0.39 & 23 & [54] \\
\hline USA & Wetland B & 3000 & 6 & 3 & 5.3 & 0.13 & 0.67 & $100 / 0$ & 28 & 0.18 & 27 & [54] \\
\hline USA & Wetland D & 8000 & 3.2 & 3 & 6.3 & 0.18 & 1.15 & $100 / 0$ & 38 & -0.30 & -26 & [54] \\
\hline New Zealand & Titoki & 898 & 1.6 & 3 & 53 & $0.26^{\mathrm{i}}$ & 14 & $15-24^{j}$ & - & -1.7 & -12 & [75] \\
\hline New Zealand & Toenepi & 293 & 1.1 & 5 & 25 & $0.07^{\mathrm{i}}$ & 1.60 & 70-93 ${ }^{j}$ & - & -1.7 & -107 & [75] \\
\hline New Zealand & Bog Burn & 113 & 0.66 & 4 & 41 & $0.30^{\mathrm{i}}$ & 12 & $36-60^{j}$ & - & -7.4 & -64 & [75] \\
\hline Switzerland & Sonnhof & 2350 & 1.2 & 2 & 34 & $0.01-1.3^{\mathrm{k}}$ & 4.67 & $75 / 25$ & $0.9-50^{\mathrm{k}}$ & 1.1 & 23 & [76] \\
\hline Italy & - & 3750 & 3 & 2 & 3.7 & 0.10 & 0.35 & - & 40 & -0.03 & -8 & [92] \\
\hline
\end{tabular}

${ }^{a}$ Average from seasonal means; ${ }^{b}$ median; ${ }^{c}$ median of discharge-weighted concentration; ${ }^{\mathrm{d}}$ data provided by the author; ${ }^{\mathrm{e}}$ only $5 \%$ of the discharge is diverted into the SFCW; ${ }^{\mathrm{f}}$ annual medians; ${ }^{\mathrm{g}}$ dissolved reactive $\mathrm{P}$ fraction; $\mathrm{h}$ assuming a constant SFCW water depth of $0.3 \mathrm{~m} ;{ }^{i}$ average from annual means; ${ }^{j}$ range of annual means for dissolved reactive $P ;{ }^{k}$ range.

The HRT (Equation (3)), also depicted below as nominal HRT (Equation (4))—commonly used by the authors-quantifies the contact time of the drainage discharge with the SFCW and is a key factor regulating $P$ retention $[76,92]$. The $P$ retention mechanisms present different requirements in terms of HRT for proper retention. The retention of PP by sedimentation, for example, commonly requires shorter HRT than that for DRP, as suspended particles transported by drainage discharge tend to 
sediment when the water velocity decreases at the inlet of a SFCW [69,76] (Figure 2). The retention of DRP, on the other hand, depends on diffusion processes regulated by concentration gradients until this $\mathrm{P}$ form is retained, e.g., by soil sorption or plant uptake $[87,88]$ (Figure 2). Therefore, the retention of $\mathrm{P}$ load consisting mainly of DRP can be more variable under different HRTs. The requirement of longer HRT for DRP can consequently limit its retention. In addition, DRP is more likely to be exported and produce a negative net retention than PP, in case the HRT is not sufficiently long $[52,75,76]$. This way, PP generally shows a major contribution to the overall mass retention of P. Braskerud [68], for example, investigated SFCWs receiving predominantly PP from the P load (average 78\%) and found that the retention of total $\mathrm{P}$ was considerably high (Figure 1) despite the short HRT. This occurred owing to an increase of particles sedimentation velocity under higher hydraulic loads (Table 1). The retention of DRP, on the other hand, was estimated at only 5\% (Figure 2). Tanner and Sukias [75], on the other hand, reported SFCWs receiving large fractions of DRP from the P load (Table 1), which generally resulted in negative net retention of total P (Figure 1; Table 1). This study demonstrated that outflow loads of DRP and total P markedly increased with shorter HRTs. Reinhardt et al. [76] similarly reported a SFCW receiving mostly DRP from the P load (62\%), and consequently a higher fraction of dissolved reactive and organic P than PP (Table 1). This study found that P retention was highly regulated by the HRT, where a minimum HRT was suggested to reach half the retention of bioavailable $P$ forms. The retention of PP from the P load, however, was considerable $(\geq 80 \%)$ and contributed to the overall mass and percentage $P$ retention.

$$
\begin{gathered}
\text { hydraulic residence time }=\frac{\text { wetland volume with active water flow }\left(\mathrm{m}^{3}\right)}{\text { water flow }\left(\mathrm{m}^{3} \mathrm{yr}^{-1}\right)} \\
\text { nominal hydraulic residence time }=\frac{\text { wetland volume }\left(\mathrm{m}^{3}\right)}{\text { water flow }\left(\mathrm{m}^{3} \mathrm{yr}^{-1}\right)}
\end{gathered}
$$

As demonstrated above, hydrochemical factors such as $\mathrm{P}$ load and dominant $\mathrm{P}$ form are normally able to estimate the mass retention of $\mathrm{P}$ in SFCWs receiving agricultural drainage discharge to a considerable degree. Other factors, however, are also responsible for the variation in mass $P$ retention and can explain, for example, the difference in performance between SFCWs receiving similar P loads and dominant $P$ form. Furthermore, attempts to estimate the percentage $P$ retention (Equation (5)) with hydrochemical factors have not attained similar explanatory power as for mass P retention [73,89], which makes the percentage retention more difficult to predict. Therefore, other factors shall also be taken into account to understand the variability in $\mathrm{P}$ retention.

$$
\text { percentage P retention }=\frac{\mathrm{P} \text { load }\left(\mathrm{g} \mathrm{m}^{-2} \mathrm{yr}^{-1}\right)-\mathrm{P} \text { load at the outlet }\left(\mathrm{g} \mathrm{m}^{-2} \mathrm{yr}^{-1}\right)}{\mathrm{P} \text { load }\left(\mathrm{g} \mathrm{m}^{-2} \mathrm{yr}^{-1}\right)} \times 100
$$

The hydraulic load (Equation (6)) normally correlates weakly to the mass and percentage $\mathrm{P}$ retention, as it does not account the P concentration $[68,73,89]$. However, it regulates the nominal HRT as well as the HRT distribution (i.e., the time for all parcels of water in the system) throughout the SFCW. This is because the hydraulic load has an inverse relationship to the nominal HRT (see Equations (4) and (6)). Moreover, the hydraulic load affects flow dynamics in SFCWs, and therefore the hydraulic efficiency (i.e., the proximity of the water flow in a CW to plug-flow conditions). During peak-flow events, for example, the hydraulic load increases and favors preferential flow and lower level of P mixing in the water. This consequently reduces the active hydrological area of the SFCW and HRT for proper P retention by the retention mechanisms. Base to moderate flow, on the other hand, attenuates the hydraulic load which tends to improve the distribution of water and $\mathrm{P}$ throughout the system. This condition increases the active hydrological area of the SFCW and HRT for P treatment and thus optimizes the retention. It is also important to note that variations in the hydraulic load commonly influence the concentration and dominant form of $\mathrm{P}$ in the drainage discharge and therefore in the inlet water of a SFCW, where higher hydraulic loads tend to increase the concentration and 
amount of PP [93]. Thus, SFCWs are subject to seasonal variations in P loads and forms due to common oscillations in hydraulic load between warm and cold periods. Therefore, hydrological factors also play a marked role on the retention of $\mathrm{P}$.

$$
\text { hydraulic load }=\frac{\text { water flow }\left(\mathrm{m}^{3} \mathrm{yr}^{-1}\right)}{\text { wetland area }\left(\mathrm{m}^{2}\right)}
$$

In a systematic review accounting mostly SFCWs receiving agricultural runoff, Land et al. [94] demonstrated through a spline regression model that percentage $P$ retention clearly increased under higher $\mathrm{P}$ concentrations when the hydraulic load was within a low to moderate range, not exceeding a critical threshold. Under this condition, the HRT is likely sufficient to allow proper retention of $\mathrm{P}$ by the retention mechanisms. However, hydraulic loads exceeding this threshold, as commonly occurring during peak-flow events, reduce the HRT and favor preferential flow, which can compromise the retention. This condition not only mitigates the $\mathrm{P}$ retention mechanisms, but also favors the resuspension of deposited sediments and subsequent export. This was observed, for example, in Geranmayeh et al. [95], where sedimentation and accumulation of P in three SFCWs increased under higher hydraulic loads-suggestively up to a critical threshold. A fourth SFCW, however, showed minor sedimentation of $\mathrm{P}$ owing to a markedly high hydraulic load $\left(400 \mathrm{~m} \mathrm{yr}^{-1}\right)$. In line with this, Land et al. [94] found that wetlands receiving event-driven hydraulic load were less effective (\%) at retaining $\mathrm{P}$ than wetlands presenting lower variations in the hydrological regime. The model for mass $\mathrm{P}$ retention presented in this study, on the other hand, demonstrated that increases in both $P$ concentration and hydraulic load resulted in higher retention. Therefore, changes in the hydrological regime may have higher consequences to the percentage $P$ retention due to variations in the export rate of $P$. This study suggests that an optimum hydraulic load shall be high enough to allow considerable mass $P$ retention, although not exceeding the threshold which would decrease the percentage $\mathrm{P}$ retention. Similarly, Reinhardt et al. [76] demonstrated through modeling that variations in the HRT presented clear effects on the percentage P retention. According to the above, however, the effect of hydraulic load on $\mathrm{P}$ retention may differ depending on the dominant $\mathrm{P}$ form in the drainage discharge, where higher loads would mostly benefit the retention of PP through sedimentation.

The hydraulic efficiency (Equation (7)) quantifies the water flow distribution along the volume of the CW and is affected by the HRT distribution [96]. Thus, increasing the hydraulic efficiency improves the retention of $\mathrm{P}$ by enhancing the level of $\mathrm{P}$ mixing across the system and the active hydrological area of the SFCW. This consequently extends the contact time of $\mathrm{P}$ to its retention mechanisms in different parts of the system. Low hydraulic efficiency, on the other hand, promotes low P retention and is commonly characterized by the presence of preferential flow and zones with slow water flow or stagnant water with limited access to the incoming P loads. Dierberg et al. [97], for example, reported low hydraulic efficiency in a SFCW due to preferential flow caused by varying density of submerged plants across the system, where areas with higher density slowed down the water flow and increased the retention of P. Sedimentation and plant uptake of $\mathrm{P}$ were consequently reduced in the areas with preferential flow, which markedly decreased the overall $\mathrm{P}$ retention. The study demonstrated that the varying retention of $\mathrm{P}$ across the SFCW occurred in response to the large distribution of HRTs. Maynard et al. [98] also reported low hydraulic efficiency in a SFCW receiving agricultural runoff due to preferential flow caused by the proximity of the inlet to the outlet. This resulted in large spatial variability in sedimentation rate and $\mathrm{P}$ sorption capacity of the soil, all affecting the retention of $\mathrm{P}$.

$$
\text { hydraulic efficiency }=\frac{\text { time of peak outflow concentration of a tracer }(\mathrm{yr})}{\text { nominal hydraulic residence time }(\mathrm{yr})}
$$

The hydraulic efficiency is not only dependent on the hydraulic load, but also highly affected by the design of the CW [96]. Su et al. [99] found that design parameters such as the aspect ratio of length to width, configuration of the inlet and outlet and obstruction designation (i.e., the aspect ratio, number 
and location of designed obstructions) had an impact on the hydraulic efficiency. Thus, the design of a SFCW influences the retention of P. Guo et al. [100], for example, demonstrated that differences in water depth, plant spacing and configuration of the inlet and outlet in a SFCW influenced outflow total P concentrations. Braskerud [101] suggested that shallow SFCWs receiving agricultural runoff can optimize the sedimentation of particles and associated P due to short settling distance, which can be beneficial in SFCWs receiving mostly PP. Moreover, the study recommended the use of vegetation cover to mitigate resuspension-a secondary effect in shallow systems-which is supported in Braskerud [90]. This latter study reported that vegetation cover reduced resuspension to approximately $40 \%$ five years after the construction of the wetlands, besides increasing the hydraulic efficiency.

As discussed above, the hydrochemical and hydrological factors play a large role on the retention of $\mathrm{P}$ in SFCWs receiving agricultural drainage discharge. The release of previously retained $\mathrm{P}$, however, is more likely affected by biogeochemical factors, which regulate transformation reactions and thus the stability of $\mathrm{P}$ in the different $\mathrm{P}$ pools (Figure 3). The export rate of $\mathrm{P}$ from a SFCW reflects both the amount of $\mathrm{P}$ not retained during its passage through the system and the amount of $\mathrm{P}$ released to the water column due to transformation reactions. As pointed out above, variations in the export rate of P may have higher consequences to the percentage P retention. In line with this, Mendes et al. [73] demonstrated that the percentage P retention depended on the stability of sediment-bound P. Therefore, it is also important to understand the effects of biogeochemical factors on internal P cycling so as to comprehend further the variability of P retention between SFCWs.

The stability of the retained $\mathrm{P}$ is crucial to determine the potential for long-term retention. The largest pools of P in a SFCW are commonly the sediments and plants and the capacity of these to store $\mathrm{P}$ largely influences the retention. Therefore, it is important to understand the factors that regulate the stability of $\mathrm{P}$ in these pools.

Geochemical characteristics largely control the stability of P in the sediments and soil of SFCWs, including transformation reactions between DRP and PP [78,79]. This is of particular importance as a considerable fraction of the incoming PP, especially P bound to clay-sized particles, can be labile and potentially bioavailable [72]. This fraction, however, can increase or decrease when passing through a SFCW, which is likely affected by the P load rate-higher load rates tend to increase the export of clay-sized particles and labile PP at the outlet [102]. As a result of this effect, the stability of P in the sediments may vary across the system. Johannesson et al. [69] found that only $22 \%$ on average of the $P$ retained in the sediments was stable (i.e., Ca-bound $\mathrm{P}$ or residual $\mathrm{P}$ ), while the $\mathrm{P}$ fraction bound to $\mathrm{Fe}$ and $\mathrm{Al}$-thus potentially labile—was almost $40 \%$ (Figure 3). Mendes et al. [80], in turn, found higher fractions of $\mathrm{P}$ bound to $\mathrm{Fe}$ and $\mathrm{Al}$ in the sediments, accounting from 58 to $100 \%$, which is considered unstable depending on the $\mathrm{pH}$ and redox conditions (Figure 3).

Dissolved reactive P normally binds to sorbents such as oxides of $\mathrm{Fe}$ and $\mathrm{Al}$, and $\mathrm{Ca}$ [79] (Figure 2). Calcium is the major P sorbent in SFCWs with mineral alkaline soils. Iron and Al oxides, on the other hand, are the most common P sorbents in SFCWs with mineral acidic soils, and the concentrations of these largely affect the stability of P. The P sorption capacity (Equation (8), where $\mathrm{Fe}_{\mathrm{ox}}$ and $\mathrm{Al}_{\mathrm{ox}}$ are oxalate extractable $\mathrm{Fe}$ and $\mathrm{Al}$ ) is a pedotransfer function which is commonly used to estimate the quantity of amorphous $\mathrm{Fe}$ and $\mathrm{Al}$ oxides (i.e., the fraction of oxides with higher sorption capacity due to larger reactive surface area) in mineral acidic soils $[80,87,103]$. Therefore, SFCWs receiving large loads of $\mathrm{Fe}$ and $\mathrm{Al}$ oxides may benefit by increasing the $\mathrm{P}$ sorption capacity in the sediments and ensure long-term retention. The increased $P$ retention as a result of Fe inputs is in fact documented by some studies $[73,80,104]$. This can be particularly the case in systems presenting high sedimentation rates of suspended particles with reactive surfaces $[80,98]$. This process can prevent the saturation of $P$ sorption sites and reduce the release rate of $P$ to the water column, which would consequently minimize the P export rate at the outlet. Mendes et al. [80], for example, reported higher P sorption capacity in the sediment layer in comparison to the soil below (Figure 3), which suggested that the 
SFCWs were being continuously supplied with P sorbents. The SFCWs investigated in this study presented percentage $P$ retentions between 41 and 51\% as reported in Mendes et al. [73].

$$
\text { P sorption capacity }=\text { constant } \alpha \times\left(\mathrm{Fe}_{\mathrm{ox}}\left(\mathrm{mmol} \mathrm{kg}^{-1}\right)+\mathrm{Al}_{\mathrm{ox}}\left(\mathrm{mmol} \mathrm{kg}^{-1}\right)\right)
$$

Iron oxides are normally the major P sorbent in SFCW soils and the saturation of this fraction is estimated by molar ratios of $\mathrm{Fe}$ to $\mathrm{P}$, including oxalate (Equation (9), where $\mathrm{Fe}_{\mathrm{ox}}$ and $\mathrm{P}_{\mathrm{ox}}$ are oxalate extractable $\mathrm{Fe}$ and $\mathrm{P}$ ) and bicarbonate-dithionite (Equation (10), where $\mathrm{Fe}_{\mathrm{BD}}$ and $\mathrm{P}_{\mathrm{BD}}$ are bicarbonate-dithionite extractable Fe and P) extractable fractions [80]. These can be a good measure of the stability of $P$ in sediments and soils where Fe oxides are the major P sorbent [88]. Zou et al. [104] reported that a molar ratio of Fe to $\mathrm{P}$ equal to 10 in the water column increased the $\mathrm{P}$ retention in comparison to a molar ratio of five. Moreover, Mendes et al. [73] demonstrated that high molar ratios at the inlet water increased the retention of $\mathrm{P}$, particularly the percentage $\mathrm{P}$ retention. In line with this, Mendes et al. [80] reported molar ratios of bicarbonate-dithionite extractable Fe to $\mathrm{P}$ in the sediments ranging from 21 to 49, which ensured high stability and consequently high retention of Fe-bound P.

$$
\begin{gathered}
\text { molar ratio of } \mathrm{Fe}_{\mathrm{ox}} \text { to } \mathrm{P}_{\mathrm{ox}}=\frac{\mathrm{Fe}_{\mathrm{ox}}\left(\mathrm{mmol} \mathrm{kg}^{-1}\right)}{\mathrm{P}_{\mathrm{ox}}\left(\mathrm{mmol} \mathrm{kg}^{-1}\right)} \\
\text { molar ratio of } \mathrm{Fe}_{\mathrm{BD}} \text { to } \mathrm{P}_{\mathrm{BD}}=\frac{\mathrm{Fe}_{\mathrm{BD}}\left(\mathrm{mmol} \mathrm{kg}^{-1}\right)}{\left.\mathrm{P}_{\mathrm{BD}}(\mathrm{mmol} \mathrm{kg})^{-1}\right)}
\end{gathered}
$$

The stability of Fe-bound P is particularly regulated by redox conditions [79] (Figure 3). Reducing conditions are common under the sediment or soil-water interface due to the consumption of terminal electron acceptors (e.g., oxygen, nitrate and sulfate by microorganisms [80]). Under these conditions, ferric Fe is reduced to ferrous Fe and concomitantly releases $P$ into the soil pore water (Figure 3). The DRP may diffuse upwards the soil profile to layers where oxidizing conditions are found, which cause the oxidation of ferrous Fe to ferric Fe with concomitant precipitation with P [79]. The lack of oxidizing conditions at the top soil layers, however, may result in the release of DRP from the soil pore water to the water column $[80,88,104]$ (Figure 3 ). This may be particularly the case during periods with higher temperatures due to increased consumption of terminal electron acceptors [80]. Therefore, the presence of an aerobic sediment or soil-water interface is essential to prevent the release of Fe-bound $\mathrm{P}$ to the water column [80]. Moreover, concentration gradients between the soil pore water and water column also control the release rate of $\mathrm{P}$, where lower $\mathrm{P}$ concentrations in the water column enhance the release $[87,88]$.

Plants can play a role on regulating the redox conditions and thus the P retention. This is because wetland plants can release oxygen to the water column through photosynthesis and support an aerobic sediment or soil-water interface. Zou et al. [104], for example, demonstrated that the presence of plants in a lacustrine wetland receiving agricultural drainage discharge increased the dissolved oxygen concentration in the water column, which contributed to the retention of Fe-bound P. Moreover, wetland vascular plants can also release oxygen to the rhizosphere though the roots, supporting the precipitation of P with Fe [105-107]. The effect on the sediments or soil redox conditions, however, is normally restricted to the root surface area (few millimeters apart) [105], which limits the influence of plants on the dynamics of $\mathrm{P}$ with Fe.

The presence of plants in SFCWs induces the transformation of inorganic $\mathrm{P}$ into organic $\mathrm{P}$ compounds through biological uptake and storage (Figure 2). This may involve the transformation of relatively stable $\mathrm{P}$ forms in the sediments or soil into unstable organic $\mathrm{P}$ forms susceptible to mineralization [108]. Thus, plants can also play a role on the biogeochemical processes which regulate the stability of $\mathrm{P}$ in the sediments by adding organic $\mathrm{P}$ to the top layers through rhizodeposition and litter fall $[69,88]$. The accumulation of organic $\mathrm{P}$ can potentially lead to $\mathrm{P}$ release in the long run due to mineralization processes (Figure 3). These processes, however, are normally retarded in 
SFCWs due to reducing conditions in the sediment layer. Further, the stability of organic $\mathrm{P}$ can vary depending on the plant species and biodegradability of the organic material [83]. The stability of this $P$ fraction in the sediments is largely controlled by enzymatic activity, and thus by the availability of terminal electron acceptors. Moreover, organic $\mathrm{P}$ transformations can be particularly regulated by hydrological fluctuations. Drawdowns followed by re-flooding may decrease the release of $\mathrm{P}$ from organic plant detritus to the water column due to consolidation of the detrital material (i.e., microbial immobilization and humification of P) [86]. Relatively long periods of drawdowns, however, may favor soil air-drying followed by the death of microorganisms, which can increase the mineralization rate of unstable organic $\mathrm{P}$ forms upon re-flooding, and thus the release of $\mathrm{P}[86,109]$. A fraction of the organic $\mathrm{P}$, however, is refractory (Figure 3 ) and thus highly stable, contributing to long-term $\mathrm{P}$ retention [79].

Surface-flow constructed wetlands are widely used as a mitigation measure to reduce the P loads from agricultural drainage discharge not only for their retention potential, but also for their capacity to operate in the long-term (Table 1) with minimal need for maintenance. These characteristics lead them to be considered cost-effective alternatives. However, the accumulation of $\mathrm{P}$ in the sediments either by sedimentation of suspended particles, sorption to reactive sites or buildup of organic $\mathrm{P}$ can negatively affect the stability of $P$ in the long-term, and thus the retention. The effects may include the saturation of $\mathrm{P}$ sorption sites and increase in the amount of unstable organic $\mathrm{P}$ forms, potentially leading to higher $\mathrm{P}$ release rates and lower net $\mathrm{P}$ retention. This scenario may be more likely in systems continuously receiving high loads of P. Old SFCWs with considerable levels of $P$ saturation and receiving low $\mathrm{P}$ loads may also present marked $\mathrm{P}$ release rates due to large differences in $\mathrm{P}$ concentration between the soil pore water and water column [78]. Mendes et al. [80] suggested that long-term retention of $P$ in SFCWs can be achieved if there is a continuous supply of excess $\mathrm{P}$ sorbents so as to ensure the availability of P sorption sites. The study also suggested that the supply of oxygen by the drainage discharge and photosynthesis is important to maintain an aerobic sediment or soil-water interface and prevent the release of Fe-bound P from the soil pore water to the water column, as the soil is normally under reducing conditions. The effects of these may not only extend the lifetime of SFCWs as P sinks but also minimize the need for maintenance. However, there is still need for more studies investigating the long-term and maturation effects of SFCWs on the retention of $\mathrm{P}$. The studies reporting mass balance analyses included in this review had monitoring periods of up to seven years (Table 1).

Maintenance operations, however, shall take place when the stability of the P retained has been significantly affected, e.g., when the conditions described above are not met. These can include periodic harvesting of plants to prevent buildup of organic P in the sediments, removal of the sediment layer and immobilization of $\mathrm{P}$ with the addition of P sorbents into the SFCW [78]. The harvest of plants, however, may be impractical due to the high costs involved and low market value of the harvested material [78]. Management operations in systems receiving high loads of PP may include a sedimentation basin constructed prior to the second wetland compartment. Mendes et al. [80], for example, reported that most of the P sedimentation in three SFCWs occurred in a sedimentation pond prior to the second wetland basin. The absence of a sedimentation basin, however, may result in high accumulation of sediments at the area near the inlet of the system [69,95]. The removal of excess sediments may be necessary to prevent resuspension during high hydraulic load events or P release from other processes. An experiment demonstrated that the removal of the organic sediment layer in mesocosms resulted in lower $\mathrm{P}$ concentrations in the overlying water, attesting the effect of sediments removal on improving the P retention performance [78]. The application of this method in SFCWs, however, can be expensive and the results may be limited [78]. Alternatively, the amendment of SFCW soils with P sorbents may be more promising. Ann et al. [110] showed that this method decreased the release of $P$ from the soil to the overlying water in a SFCW. Moreover, Ballantine and Tanner [111] reviewed a range of materials potentially useful in the amendment of SFCW soils. The review found that allophane, Papakai tephra, limestone and alum demonstrated the highest potential, considering the P retention characteristics, availability in New Zealand and cost. This study also indicated the potential for 
removing the saturated topsoil with $\mathrm{P}$ or mixing it with the subsoil as a measure to prevent $\mathrm{P}$ release. The effect of maintenance operations on increasing the lifetime of SFCWs as P sinks when receiving agricultural drainage discharge, however, is still poorly reported in the literature.

Despite the advantages of SFCWs as a measure to reduce the P loads, the common requirement of large areas to allow sufficient HRT and achieve acceptable P retention (Table 1) is a major limiting factor for their application, especially in lands highly used for agriculture. Systems receiving high $P$ loads may benefit from smaller areas in order to increase the area specific mass retention of P. However, lower $\mathrm{P}$ concentrations at the outlet are normally achieved at the expense of larger SFCW areas, and consequently higher ratios of SFCW area to the agricultural catchment area [78]. Systems receiving large loads of PP, however, may require smaller areas to achieve acceptable P retention than systems predominantly receiving loads of DRP (as suggested by Table 1), owing to the different requirements in terms of HRT as discussed above. Therefore, the area requirement may vary depending on the catchment characteristics, e.g., $\mathrm{P}$ load and dominant $\mathrm{P}$ form, and the $\mathrm{P}$ retention goal.

Horizontal or vertical subsurface-flow constructed wetlands can be an advantage in relation to SFCWs in regards to smaller area requirements. Li et al. [112] demonstrated that five newly constructed experimental horizontal-flow wetlands effectively retained $\mathrm{P}$ from agricultural drainage discharge $(35 \%, 38 \%, 38 \%, 57 \%$ and $31 \%)$, which was likely owing to the unsaturated medium with P. The study also demonstrated that the percentage P retention increased after the addition of a carbon source, which probably favored microbial uptake of $\mathrm{P}$, and under longer HRTs. The use of subsurface-flow constructed wetlands, however, is largely restricted to the treatment of wastewater (e.g., sewage) and is less used in agricultural catchments than SFCWs due to high maintenance costs, risk of clogging and limited P sorption capacity of the medium [113].

Other limitations of SFCWs include the low retention potential for agricultural drainage discharge dominated by DRP as discussed above, unless the inlet water carries considerable amounts of $P$ sorbents or the P sorption capacity of the SFCW soil is markedly high to allow acceptable and long-term P retention.

Therefore, cost-efficiency assessments are necessary to evaluate the feasibility of SFCWs as an appropriate measure to reduce P loads. The costs of SFCWs are related to land acquisition, construction, energy consumption (e.g., pumping in flat lands) and maintenance. Gachango et al. [114] reported that these systems were able to retain $\mathrm{P}$ at relatively low cost $\left(€ 55-1148 \mathrm{~kg}^{-1} \mathrm{P}\right)$ in comparison to other measures. Moreover, the cost-efficiency improved when the SFCWs received higher P loads. Thus, implementation of SFCWs in agricultural catchments characterized by marked P loads may be beneficial. Despite the great importance of cost-efficiency assessments for decision-making on the implementation of SFCWs in specific catchments, the literature addressing this issue is still limited.

\subsection{Restored Wetlands}

Differently from CWs, which are built in sites where no natural wetland previously existed, RWs are implemented with the aim to reestablish a wetland which was drained for the expansion of agriculture [79]. Thus, the restoration of wetlands generally occurs in areas previously used for agriculture, where the original physical and chemical composition of the soil had been changed as a result of agricultural practices [115]. The process of restoration in tile-drained agricultural catchments occurs by disconnecting the main drainage pipe at the border of a lowland field so as to allow the discharge water to flood over a certain area before reaching downstream surface waters. This consequently increases the HRT of the drainage discharge and allows interaction between the water and soil as well as biogeochemical processes.

Wetlands are restored with the main goal of reducing the load of nutrients from upstream agricultural catchments to surface waters, as for CWs. This can be advantageous for the removal of nitrogen if the restoration is performed in soils previously enriched with carbon, which would support denitrification. In relation to P, RWs are normally effective in the retention of PP through sedimentation, whereas the effect on DRP may be uncertain [116]. This is owing to previous agricultural practices 
such as $\mathrm{P}$ inputs through mineral fertilizers or manure, which likely enriched the soil with $\mathrm{P}$ and consequently reduced the availability of $\mathrm{P}$ sorption sites. This effect can result in a $\mathrm{P}$ concentration gradient across the soil-water interface upon re-flooding, where desorption of $\mathrm{P}$ followed by diffusion to the water column would be potentially favored. This release process can be intensified if the inlet water carries low P concentrations. Moreover, the emergence of reducing conditions at the topsoil as soon as it is re-flooded supports the release of Fe-bound P to the water column $[117,118]$. Thus, it is essential that the topsoil layers contain sufficient amounts of redox-stable P sorbents (e.g., $\mathrm{Al}$ and Ca) to precipitate with $\mathrm{P}$ and prevent its release [118]. Finally, the accumulation of organic $\mathrm{P}$ from previous crop rotations may support mineralization and release of dissolved reactive and organic $P$ under waterlogged conditions [117]. The effects described above create uncertainty on the potential of RWs as sinks for DRP. This can counteract the retention of PP and result in large variability in the net $P$ retention between systems, from P sinks to P sources (Table 2). Despite the uncertain sorption capacity of RW soils, other retention mechanisms for DRP such as biological uptake by plants and microorganisms can support net P retention [117], although these are short-term P pools, as discussed in the previous section. Therefore, it is crucial to determine the $\mathrm{P}$ sorption capacity and level of $\mathrm{P}$ saturation of the soil prior to wetland restoration in order to ensure retention of DRP.

Hoffmann et al. [119] demonstrated that two out of four RWs were able to retain P (Table 2). The net $P$ release observed in the remaining RWs was likely caused by excess accumulation of $P$ in the soils from previous agricultural practices and emergence of reducing conditions upon re-flooding. Net and modest P releases were also found in Hoffmann et al. [120] (Table 2), despite the large amounts of $\mathrm{P}$ in the topsoil and low $\mathrm{P}$ concentrations in the inlet water. This study suggested that the stability of $\mathrm{P}$ in the topsoil was controlled by sorption processes, where high molar ratios of $\mathrm{Fe}$ to $\mathrm{P}$ and oxidizing conditions likely supported the P stability in spite of the conditions described above. These observations were supported to some extent by Hogan et al. [121], who demonstrated that the P sorption capacity of RW soils receiving agricultural runoff may be markedly high, even exceeding those of natural wetlands. Woltemade [122], in turn, reported contrasting results to Hoffmann et al. [120], with net P retention reaching approximately $20 \%$ in RWs (Table 2), despite the predominance of dissolved $\mathrm{P}$ in the inlet water.

Table 2. Average annual hydraulic and phosphorus $(\mathrm{P})$ load as well as mass $\mathrm{P}$ retention of restored wetlands (RWs) receiving agricultural drainage discharge investigated in different studies. Included are the RW areas $\left(\mathrm{A}_{\mathrm{RW}}\right)$ and their ratios to the agricultural catchment areas $\left(\mathrm{A}_{\mathrm{AC}}\right)$ as well as the average $P$ concentration and percentage $P$ retention for the entire monitoring period.

\begin{tabular}{|c|c|c|c|c|c|c|c|c|c|c|}
\hline \multirow{3}{*}{$\begin{array}{l}\text { Country } \\
\text { Denmark }\end{array}$} & \multirow{3}{*}{$\begin{array}{l}\text { Name } \\
\text { lleruplund }\end{array}$} & \multirow{3}{*}{$\begin{array}{c}\mathbf{A}_{\mathrm{RW}} \\
\mathbf{m}^{\mathbf{2}} \\
130,000\end{array}$} & \multirow{3}{*}{$\begin{array}{c}\begin{array}{c}\text { Ratio of } \\
\mathbf{A}_{\mathrm{RW}} \text { to } \\
\mathbf{A}_{\mathrm{AC}}\end{array} \\
\% \\
21.7\end{array}$} & \multirow{3}{*}{$\begin{array}{c}\begin{array}{c}\text { Monitoring } \\
\text { Time }\end{array} \\
\text { yr } \\
1\end{array}$} & \multirow{3}{*}{$\begin{array}{c}\begin{array}{c}\text { Hydraulic } \\
\text { Load }\end{array} \\
\mathrm{m} \mathrm{yr}^{-1} \\
0.4\end{array}$} & \multirow{3}{*}{$\begin{array}{c}\begin{array}{c}\mathbf{P} \\
\text { Concentration }\end{array} \\
\mathbf{m g ~ L}^{-\mathbf{1}} \\
0.03\end{array}$} & \multirow{2}{*}{$\begin{array}{c}\text { P Load } \\
\mathrm{g} \mathrm{m}^{-}\end{array}$} & \multicolumn{2}{|c|}{ P Retention } & \multirow{3}{*}{$\begin{array}{r}\text { Study } \\
\\
{[119]}\end{array}$} \\
\hline & & & & & & & & $\mathrm{yr}^{-1}$ & $\%$ & \\
\hline & & & & & & & 0.01 & -0.04 & -88 & \\
\hline Denmark & Snaremose & 340,000 & 6.6 & 2 & - & - & 1.43 & 0.26 & 18 & [119] \\
\hline Denmark & Lindkær & 840,000 & 9.2 & 1.4 & - & $0.07-0.93^{\mathrm{a}}$ & 0.45 & -0.05 & -11 & [119] \\
\hline Denmark & Stor A & 5870 & 2.4 & 2 & 4.8 & $0.02^{b}$ & 0.11 & -0.06 & -56 & [120] \\
\hline USA & Embarras River & $6000-8000$ & $3.3-4.0$ & - & - & - & - & - & 20 & [122] \\
\hline
\end{tabular}

${ }^{\mathrm{a}}$ Range; ${ }^{\mathrm{b}}$ average from annual means.

Restored wetlands have been mostly used as floodplains in riparian areas in order to reduce the load of nutrients in surface waters during flood events [116]. Thus, most of the literature in relation to RWs addressed these issues. Assessments on the potential of RWs in the retention of P from agricultural drainage discharge are, therefore, limited by the small number of studies. It has been suggested, however, that RWs may be a potential source of $\mathrm{P}$ in the initial period of operation due to previous agricultural practices and the associated effects described above [77,115-117]. The release of considerable amounts of $\mathrm{P}$ from the soil over an initial period and/or enrichment with $\mathrm{P}$ sorbents from the drainage discharge may, however, turn RWs into P sinks. On the other hand, gradual loss of $\mathrm{P}$ 
sorbents from RW soils upon re-flooding, thus decreasing the P sorption capacity, is also feasible [121]. Therefore, it is fundamental to investigate the operating performance of RWs in the long-term to find out common patterns under different conditions. The systems included in this review were monitored for up to two years only (Table 2).

Management methods to increase the efficiency of RWs may include the removal of the enriched topsoil with $\mathrm{P}$ prior to implementation, as tested in a wetland constructed on former agricultural soil receiving agricultural runoff [123]. Hoffmann et al. [120], in turn, suggested a periodic harvest of the vegetation in order to maintain or improve the retention capacity of the soil when the pool of organic $P$ becomes large in relation to the annual P load.

As for CWs, the main constraint in the implementation of a RW refers to the need of land which would otherwise be used for agriculture [77]. Strategic restoration plans, therefore, may focus on marginal agricultural areas less profitable for farming, optimal sizing and design [124]. Woltemade [122] pointed out that $P$ retention in RWs is highly sensitive to variations in HRT, which could be related to the effects associated to previous agricultural practices and likelihood of $\mathrm{P}$ release. This could be verified in Jordan et al. [125], where large variations in water flow throughout the monitoring period resulted in marked differences in P retention in RWs receiving agricultural runoff. Woltemade [122], thus, suggested that the ratio of the RW area to the catchment area shall be high enough to allow sufficient HRT and ensure acceptable P retention. Indeed, this ratio is generally much higher for the RWs presented here (Table 2) in comparison to the SFCWs (Table 1). Consequently, lower hydraulic and P loads are generally observed in RWs (Table 2) than in SFCWs (Table 1). An intrinsic problem to this is the need of large areas for wetland restoration. Therefore, RWs may be recommended in catchments where P can be properly retained at the expense of relatively short HRTs, which would minimize the size of the area needed. This could be the case in tile-drained catchments characterized by the predominance of PP and/or soils containing high molar ratios of P sorbents to P, despite the previous agricultural practices.

\subsection{Vegetated Buffer Strips}

As opposed to CWs and RWs, which are waterlogged systems, VBSs do not hold water over the soil surface. These systems are naturally occurring or implemented between the edge of an agricultural field or catchment and running surface waters such as rivers and streams in order to intercept and reduce the load of nutrients downstream as well as to increase the bank stability and prevent erosion [126-128]. Thus, they may contain native or planted vegetation consisting of species of forest plants and/or grass [129].

Vegetated buffer strips are normally used to reduce the nutrient load from agricultural surface and subsurface runoff in catchments lacking a tile drainage system. The retention of $\mathrm{P}$ from agricultural runoff mainly occurs through entrapment of PP in the soil matrix or by the vegetation, where larger particles are more easily retained than fine clay particles [126,130]. This retention mechanism is benefited in these systems due to infiltration of the runoff into the soil and enhanced hydraulic roughness of the vegetation, which decrease the water flow velocity and particles transport, and subsequently favor deposition $[127,128]$. The retention of DRP is mediated by plant uptake in the root zone during the growing season and sorption to reactive sites in the soil profile, and is thus influenced by the level of runoff infiltration as well $[128,129]$. However, VBSs tend to decrease the retention of $\mathrm{P}$ in the long-term or even become a source of dissolved reactive and organic $\mathrm{P}$ due to saturation of sorption sites and/or release of $\mathrm{P}$ from senescing plants $[127,128,130,131]$. Therefore, the soil geochemical characteristics (e.g., P sorption capacity) and vegetation composition and density markedly affect the retention efficiency of dissolved P. Despite that, the higher retention efficiency of PP than that of DRP commonly results in higher ratios of dissolved $P$ to total $P$ at outflows than at inflows [132]. A suggested management method to prolong the retention of dissolved P may involve periodic harvesting of vegetation to enhance plant uptake and prevent release from mineralization [131], presumably before the end of the growing season. 
The studies dealing with agricultural surface and subsurface runoff demonstrated that VBSs generally work as P sinks, especially for PP. Uusi-Kämppä and Yläranta [133], for example, tested the ability of VBSs to mitigate the loss of PP from agricultural areas owing to soil erosion, and found that these systems reduced by $20 \%$ and $36 \%$ the PP losses in comparison to sites with no VBS. Nevertheless, it is normally observed a large variability in P retention between systems $[126,127,134]$. Part of the variability can be attributed to the incoming P concentration and to the ratio of the system area to the catchment area [134]. Moreover, the width of VBSs has been widely discussed in relation to P retention. It has been commonly found that wider systems enhance P retention [126-128,130], especially on steeper slopes [131]. However, widening a VBS consequently reduces the land area for agriculture. Therefore, attempts to estimate the optimal width for acceptable P retention under specific catchment characteristics (e.g., slope, soil clay content and drainage pattern) are highly desired [128].

In tile-drained agricultural catchments, however, the P load may bypass the plant root zone and soil profile, and be directly discharged to downstream surface waters, thus skipping the P retention mechanisms [127-129]. Osborne and Kovacic [129] indicated the limitation of VBSs in this situation when compared to the treatment of groundwater. The discharge of concentrated P load from tile drains into VBSs may, on the other hand, overload the P retention mechanisms and consequently decrease the P retention efficiency [126]. As a result, VBSs are rarely used to treat agricultural drainage discharge. Therefore, the literature addressing the treatment of agricultural drainage discharge by VBSs is rather limited. Bhattarai et al. [135] pioneered this investigation and documented the effect of a tile drain on the retention of P by a VBS. The study demonstrated that the tile drain helped to prevent inundation of the system during periods of high water runoff. In relation to P retention, it showed that the concentrations of total P and DRP decreased at the outlet of the tile drain after the P load passed through the system. However, there was no evidence of $P$ accumulation in the system.

A promising alternative technology combining a ditch-like pond with a slightly inundated VBS to retain $P$ from agricultural drainage discharge was recently proposed by Zak et al. [136]. This design allowed the drainage water to discharge into the system without bypassing it. The study showed that the system retained from 31 to $69 \%$ of the $\mathrm{P}$ load on average per month, despite the low ratio of the system area to the agricultural catchment area of around $0.1 \%$. Moreover, the system also proved to effectively retain DRP, most likely by plant uptake in the pond and by sorption through the VBS. The design was suggested as a modification to the conventional VBSs when targeting high P loads from tile drains. In line with this, Osborne and Kovacic [129] recommended the use of CWs integrated with VBSs as a second treatment stage in order to properly treat drainage discharge.

The experiences from previous studies indicate, therefore, that VBSs may be viewed as a complement to design alternatives attempting to attain acceptable $P$ retention in tile-drained agricultural catchments. The alternative systems should primarily avoid the bypass of $\mathrm{P}$ loads and enhance the retention mechanisms for DRP (e.g., by using substrates with adequate infiltration level and P sorption capacity).

\subsection{Filter Materials}

The edge-of-field technologies described above are especially effective in the retention of PP from agricultural drainage discharge. The retention of DRP, on the other hand, can be rather poor or highly variable between systems and under different periods, thus being generally less predictable. Loads of dissolved P can be harmful to surface waters as these largely include P reactive forms readily available for biological uptake, potentially causing eutrophication. Therefore, it is crucial that alternative technologies are tested in relation to retaining DRP at acceptable levels. These include a range of filters containing P sorption materials with varying sorption capacities and hydraulic conductivities. These systems are advantageous in relation to the previously described edge-of-field technologies in the sense that little or no agricultural land is needed for implementation, making them less costly. A large part of the literature describes the potential of FMs for P retention from various types of effluents through batch and column experiments. This section, however, is restricted to those filters implemented at 
the outlet of tile drains or tested with simulated agricultural drainage discharge under laboratory conditions aiming at $\mathrm{P}$ retention.

Filters include natural, synthetic and industrial by-product materials, which contain metal cations and are able to retain $\mathrm{P}$ through sorption, thus forming insoluble $\mathrm{P}$ compounds. They are built so as to allow the discharge to flow through the system at a sufficient rate and without the risk of immediate clogging, taking into account average local precipitation. The materials are porous and rich in $\mathrm{P}$ sorbents such as $\mathrm{Fe}, \mathrm{Al}, \mathrm{Mg}$ and/or $\mathrm{Ca}$, thus with a high affinity for $\mathrm{P}$. They are expected to retain $\mathrm{P}$ even at low inflow $\mathrm{P}$ concentrations and present low $\mathrm{P}$ desorption rate, allowing a gradual decrease in the concentration of DRP from the inlet to the outlet [137]. The retention mechanisms for DRP in FMs include chemisorption or ligand exchange onto the surface of sorption sites in Fe and Al-based filters, and precipitation in $\mathrm{Mg}$ and Ca-based filters [138].

Batch experiments are important to test the P sorption potential of FMs prior to implementation in the field. A series of materials with different compositions were assessed in relation to solutions containing P and simulating agricultural drainage discharge. The studies generally considered a number of FMs tested for a variety of particle size intervals, $\mathrm{P}$ concentrations and HRTs. These have shown that Fe and Al-based filters are usually superior to those based on $\mathrm{Mg}$ and $\mathrm{Ca}$ [139-141]. Lyngsie et al. [139], for example, demonstrated that the Fe-oxide based filter CFH presented higher P sorption capacity, reactivity and stability than the Ca-based filters limestone, calcined diatomaceous earth and shell-sand. CFH was also superior to Filtralite-P when the P concentration of the solution was low $(16 \mu \mathrm{M})$. The study found that the finest CFH (particle size interval of $0.05-0.5 \mathrm{~mm}$ ) was the only FM recommended for extreme field conditions, i.e., high and low water flows and P concentrations. The superiority of $\mathrm{CFH}$ for P retention to the FMs mentioned above was also demonstrated in Canga et al. [140], where Filtralite-P reached an approximate efficiency. Lyngsie et al. [141] reported similar results to the above and related the higher efficiency of $\mathrm{CFH}$ to fast and strong bonds of $\mathrm{P}$ to $\mathrm{Fe}$ on outer surfaces of the material followed by migration of $\mathrm{P}$ to interior sorption sites, while retention of $\mathrm{P}$ in Filtralite-P and limestone by precipitation depended on $\mathrm{pH} \geq 10$ and long HRT, respectively. This study also found CFH suitable for application at the outlet of tile drains, while Filtralite-P and limestone presented limitations. Allred and Racharaks [142] demonstrated that other Fe-based FMs, including zero-valent Fe, porous Fe composite, sulfur modified Fe and Fe oxide/hydroxide were also highly effective in retaining $\mathrm{P}(\geq 95 \%)$ for $\mathrm{P}$ concentrations in solution up to $100 \mathrm{mg} \mathrm{L}^{-1}$. Iron oxide/hydroxide, however, proved to be the most efficient, with P retention reaching $99 \%$ when the solution contained $1000 \mathrm{mg} \mathrm{P} \mathrm{L}^{-1}$. This study indicated that $\mathrm{P}$ was not readily desorbed once it bound to these materials, and that the hydraulic conductivity of the filters was high in most cases $\left(>0.01 \mathrm{~cm} \mathrm{~s}^{-1}\right)$, supporting their potential use in the field. Additional experiments confirmed the viability of porous Fe composite in the treatment of agricultural drainage discharge both in terms of $\mathrm{P}$ retention and hydraulic conductivity [143]. Filters comprised by surfactant-modified zeolite and high Ca oxide-high carbon fly ash also presented effective P retention ( $\geq 50 \%)$ for solutions ranging from 0.1 to $1 \mathrm{mg} \mathrm{P} \mathrm{L}^{-1}$ during 1 to $24 \mathrm{~h}$ of HRT [144].

Batch experiments are valid to give an indication of the potential of FMs for field application. However, these may sometimes overestimate the performance, as hydrological factors are not taken into account. Column experiments, on the other hand, are designed to test the potential of FMs for $\mathrm{P}$ retention under varying water flow conditions. Canga et al. [140], for example, demonstrated that FMs with non-equilibrium transport (CFH and seashells) were capable of higher P retention and lower P release (P desorption) compared to those where an equilibrium flow was reached (Filtralite-P and limestone). The study showed that $P$ retention could be further increased in the filters with non-equilibrium transport by increasing the water flow, as it supported $\mathrm{P}$ concentration gradients between mobile and immobile pore regions and ultimately the diffusion and sorption of P. This way, the study characterized intragranular $\mathrm{P}$ diffusion as an important $\mathrm{P}$ retention mechanism. Other FMs, including a mixture of activated carbon, zeolite and activated alumina also demonstrated potential in the treatment of $\mathrm{P}$ from agricultural drainage discharge, with average $\mathrm{P}$ retention of $52 \%$ in a 
laboratory experiment [145]. Column studies were also important to attest the extreme efficiency ( $\geq 90 \%$ P retention) of the Fe-based filters zero-valent Fe, porous Fe composite, sulfur modified Fe and Fe oxide/hydroxide, regardless of water flow and HRT (down to 2.5-4.0 min), highlighting how quickly $P$ sorption reactions occur in these materials [142].

Although column studies investigate the feasibility of FMs for field application, it is often recommended that these are further tested in small and/or large-scale experimental setups in the long-term and under varying conditions (e.g., P load and HRT) prior to field implementation. Kirkkala et al. [146] tested the retention performance of a sand filter enhanced with a layer of the $P$ binding material Fosfilt-s and receiving agricultural drainage discharge for 3.5 years. The filter retained on average $0.03 \mathrm{~g} \mathrm{~m}^{-3} \mathrm{~d}^{-1}(37 \%)$ of total P and $0.04 \mathrm{~g} \mathrm{~m}^{-3} \mathrm{~d}^{-1}(45 \%)$ of DRP, as a result of proper water distribution. The study concluded that incorporation of Fosfilt-s to sand filters can be recommended for $P$ retention from agricultural drainage discharge, where the concentration of suspended particles-a precursor to clogging-is normally low. Moreover, McDowell et al. [49] demonstrated that a filter comprised of a mixture of melter slag $(90 \%)$ and basic slag $(10 \%)$, and inserted at the outlet of tile drains reduced the loads of total $\mathrm{P}$ and DRP in relation to control drains backfilled with greywacke aggregate by 63 and $69 \%$, respectively. Finally, Ballantine and Tanner [111] reported that not only slag, but also limestone, seashells, shell-sand and tree bark were the most promising FMs in retaining $\mathrm{P}$ from the effluent of SFCWs receiving agricultural drainage discharge, when considering the retention potential, availability in New Zealand, cost and potential for reuse upon saturation. The studies above were important to investigate the applicability and limitations of FMs under field conditions for future considerations. However, most of the studies with FMs targeting agricultural drainage discharge were conducted in the laboratory. More field studies covering a number of locally available FMs are therefore essential to ascertain their successful application.

Woodchip bioreactors are implemented in agricultural catchments to remove nitrogen through denitrification due to their large carbon contents and anaerobic medium. Gottschall et al. [147], however, tested the effect of this filter medium on the retention of $\mathrm{P}$ as well. It was found that these systems retained on average $0.21(21 \%)$ and $0.30(19 \%) \mathrm{g} \mathrm{m}^{-3} \mathrm{~d}^{-1}$ of the total P and DRP loads, respectively, which may be attributed to $\mathrm{P}$ immobilization into organic forms. The percentage $\mathrm{P}$ retention more than tripled when the bioreactors were amended with alum-based drinking water treatment plant residuals ( $10 \%$ of the bioreactor volume). This finding highlighted the applicability of materials for P retention to systems originally designed to remove nitrogen.

Alternatively, other studies proposed pairing woodchip bioreactors with FMs. Carstensen et al. [148], for example, found that although a woodchip bioreactor mixed with crushed mussel shells $(25-50 \%$ of the bioreactor volume) retained from 29 to $33 \%$ of the total P load-largely in the form of PP-the retention of phosphate varied from net annual release to retention. Thus, the study suggested pairing the bioreactor with a FM to increase the phosphate retention efficiency. In general, this approach is likely more beneficial, as there would be no need for homogeneous mixing of two or more different mediums, which can be difficult to achieve at the field scale, so as to prevent preferential flow. Moreover, the FM could be easily replaced or rejuvenated upon saturation [149]. Christianson et al. [149], for example, tested filters comprised of either acid mine drainage treatment residuals (Fe-based) or steel slag (Ca-based) and paired downstream of woodchip bioreactors under HRTs from 7.2 to $51 \mathrm{~h}$. On average, the study found that the former filter alone retained DRP from 25 to $133 \mathrm{~g} \mathrm{~m}^{-3} \mathrm{~d}^{-1}$ (corresponding to $98 \%$ and $58 \%$, respectively, in the paired system), while the latter filter alone retained from 8.8 to $48 \mathrm{~g} \mathrm{~m}^{-3} \mathrm{~d}^{-1}$ (corresponding to $26 \%$ and $36 \%$, respectively, in the paired system). Goodwin et al. [150] also found significant $P$ retention values when testing the pairing of an Fe-based filter comprised of steel turnings downstream a woodchip bioreactor. In this study, near complete orthophosphate retention was achieved in the paired system. A comparable effective retention of phosphate by steel by-products treating the effluent of a woodchip bioreactor (65\% retention) was reported by Hua et al. [151]. Here, the retention of phosphate in the bioreactor alone was relatively high and ranged on average from 0.25 to $0.88 \mathrm{~g} \mathrm{~m}^{-3} \mathrm{~d}^{-1}$ (corresponding to $56 \%$ and $17 \%$, respectively). In contrast, a large variability in the 
retention of DRP by a filter comprised of steel shavings and placed downstream a woodchip bioreactor was observed in Thapa [152]. This study reported $P$ retention in the filter alone ranging from 2.2 to $184 \mathrm{~g} \mathrm{~m}^{-3} \mathrm{~d}^{-1}$ with an average $49 \mathrm{~g} \mathrm{~m}^{-3} \mathrm{~d}^{-1}(10-90 \%$ and average $45 \%)$.

The studies above suggested placing the FM downstream the woodchip bioreactor for optimal P retention. They demonstrated that an opposite configuration could lead to the release and export of $P$ from the paired system - potentially increased under longer HRTs [150]—due to the emergence of reducing conditions in the effluents originated from the bioreactor as a result of denitrification, which support the release of Fe-bound P. An exception to the optimal configuration could be when the HRT in the woodchip bioreactor is sufficiently long to export highly reduced effluents to the filter, which could inhibit $\mathrm{P}$ sorption in the material and/or favor P desorption and release [149]. If this is often the case, placing the FM upstream the bioreactor may optimize the retention of $P$.

The variability in P retention between FMs is largely caused by differences in HRT and inflow $\mathrm{P}$ concentration $[153,154]$. It is generally observed that higher mass $\mathrm{P}$ retention is found under increasing water flows, while percentage P retention enhances under longer HRTs, i.e., lower water flows $[145,147,149,155]$. This is because increasing water flows implies higher P loads for cumulative retention in a fixed volume and time period, although this reduces the contact time for a fraction of the P load to be retained [154]. The short response of P retention to these hydrological factors, considering the relatively small volume of filters, can result in marked variability in P retention when receiving event-driven drainage discharge. The inflow $\mathrm{P}$ concentration, on the other hand, normally contributes positively to both mass and percentage $\mathrm{P}$ retention, as it supports sorption reactions with $\mathrm{P}$ sorbents [146,154,156].

The material of the filter reflects a specific P sorption capacity and hydraulic conductivity (Equation (11)), which also affect the P retention performance. An ideal material would have a high capacity for $\mathrm{P}$ sorption as well as rapid hydraulic conductivity. However, it is common for these parameters to correlate inversely [137]. This is because FMs tend to increase the P sorption capacity with smaller particle sizes, as these reflect on larger surface areas for P sorption [139]. Smaller particle sizes, on the other hand, decrease the filter porosity and hinder the water flow, decreasing consequently the hydraulic conductivity.

$$
\text { hydraulic conductivity }=\frac{\text { water flow }\left(\mathrm{m}^{3} \mathrm{yr}^{-1}\right)}{\text { cross }- \text { sec tional area }\left(\mathrm{m}^{2}\right) \times \text { hydraulic gradient }}
$$

The content and forms of specific P sorbents in the material affect the P sorption capacity and retention [138]. Filters based on Fe and $\mathrm{Al}$ are recommended when the HRT in the system is relatively short, i.e., high water flows, due to fast ligand exchange with $\mathrm{P}$ in comparison to those based on $\mathrm{Mg}$ and $\mathrm{Ca}$, in which precipitation reactions are comparatively slower $[138,153,154]$. Thus, the former filters are generally more efficient and can retain more $\mathrm{P}$, whereas the latter may be suitable in situations where the HRT is relatively long and P concentrations are lower (e.g., $<2 \mathrm{mg} \mathrm{L}^{-1}$ [138]) [154]. This was clearly demonstrated in a flow-through setting by Lyngsie et al. [156], where the Fe-based filter CFH presented a P sorption capacity and affinity 10 times higher than the Ca-based filter Filtralite-P. The study also demonstrated that $\mathrm{P}$ release from previously sorbed $\mathrm{P}$ was lower in $\mathrm{CFH}(<10 \%)$ than in Filtralite-P ( $\geq 35 \%)$. Finally, it was observed that $\mathrm{CFH}$ was able to retain $\mathrm{P}$ even at high water flows, while Filtralite-P depended on sufficiently long HRTs for proper retention. The study concluded that CFH was preferred in catchments with varying P concentrations and HRTs.

Moreover, Fe and Al-based filters with a higher fraction of amorphous than crystalline oxides enhance $\mathrm{P}$ retention due to higher reactivity of the former forms, while retention in $\mathrm{Mg}$ and Ca-based filters depends on the water solubility of the different forms-commonly controlled by the discharge $\mathrm{pH}$ - so as to allow precipitation with P [138]. Therefore, a faster precipitation of $\mathrm{P}$ in $\mathrm{Mg}$ and Ca-based filters can be observed when the material has a high and buffered $\mathrm{pH}(>8)$, which enhances the sorbents solubility [154]. The complex inherent composition of FMs ultimately contributes to the large variability in P retention. This consequently hinders or impedes direct comparisons between 
filters. Penn et al. [154] discussed that normalizing P retention as a function of $\mathrm{P}$ addition per unit mass of the FM facilitates comparisons between filters as the cumulative P load is taken into account. However, the study indicates that variations in HRT and inflow P concentration can still make proper comparisons difficult.

The $\mathrm{pH}$ of the discharge is also important to determine the proper FM so that $\mathrm{P}$ sorption and retention can be optimized. Phosphorus retention increases in Fe and Al-based filters when the discharge $\mathrm{pH}<7.5$, which supports positive charge sites in the material and decreases the competition of phosphate with hydroxides for sorption sites [153]. Filters based on $\mathrm{Mg}$ and $\mathrm{Ca}$, on the other hand, optimize P retention when the discharge $\mathrm{pH}>6$ [153], which enhances the sorbents solubility and precipitation with P. In general, the $\mathrm{pH}$ of a FM is recommended to be between 5.5 and 7.5 for optimal $\mathrm{P}$ sorption and retention as well as to protect downstream aquatic ecosystems from effluents with detrimental $\mathrm{pH}[138]$.

Design parameters, including the mass and volume of the material used and the configuration of the filter (e.g., water flow direction), also affect the retention of $\mathrm{P}$ [137]. Therefore, it is important to understand the catchment conditions (e.g., load of DRP) prior to filter implementation in order to determine the proper material and design for acceptable P retention within a time period (i.e., the filter lifetime). In other words, a successful design will ultimately have the appropriate sizing to target a retention goal based on the $P$ inputs into the system. This can be achieved with the so-called design curve, which estimates $P$ retention based on the amount of $P$ added per unit mass of the FM, and therefore calculates the required mass of the material [154].

The efficiency of FMs will eventually decrease over time due to saturation of P sorption sites until a moment when it is no longer able to retain $\mathrm{P}$. The lifetime of a filter will primarily depend on the $\mathrm{P}$ sorption capacity, P load and water flow dynamics. Therefore, the configuration of the filter shall allow replacement or rejuvenation of the material after it becomes spent. Moreover, the use of FMs may be limited to agricultural catchments with marked concentrations of DRP (e.g., $>0.2 \mathrm{mg} \mathrm{L}^{-1}$ ) [137,154]. This is because low $\mathrm{P}$ concentrations during long periods will likely reduce the ability of filters to sorb $\mathrm{P}$ due to equilibrium reactions between the amounts of $\mathrm{P}$ sorbed and the low $\mathrm{P}$ concentration in the flow discharge. Therefore, the implementation of these systems may be restricted to catchments characterized by high loads of DRP. The use of filters is also restricted if the material contains considerable amounts of heavy metals prone to leaching, which could harm downstream aquatic ecosystems. This is particularly the case when the discharge $\mathrm{pH}$ and redox conditions favor the solubility of these elements [138].

A few studies carried out cost-efficiency assessments to determine the feasibility of treating DRP with FMs. Common costs include the mass of the material used and the area needed, being these regulated by the P load, retention goal and expected lifetime of the filter [154]. Thapa [152], for example, found an estimated cost of $\$ 209 \mathrm{~kg}^{-1}$ DRP in a filter of steel shavings, which the author considered expensive. Additional construction costs (e.g., large amount of material mass and area) may incur if the design of a certain FM shall enable long HRTs in catchments characterized by high water flows. As discussed above, FMs based on $\mathrm{Fe}$ and $\mathrm{Al}$ are less sensitive to variations in HRT, and may thus lower the costs under high water flow conditions. This highlights the impact of a specific material on the costs. Moreover, industrial by-products are generally considered cheap and readily available in comparison to naturally occurring materials, which may depend on mining and transportation costs. The lifetime of the FM will also influence the costs. It is considered that rejuvenating spent materials for reuse instead of replacing them will contribute to improve the cost-efficiency [154]. However, this needs to be investigated, where results in this direction would support the use of filters.

\section{Conclusions and Perspectives}

A series of edge-of-field technologies have been investigated and implemented in tile-drained agricultural catchments in order to reduce the excess loads of $P$ to downstream surface waters and prevent eutrophication. The review observed that the catchment characteristics and system design 
regulate the hydrochemical, hydrological and biogeochemical factors, which all affect the P retention performance. Moreover, it became clear that HRT is a key factor regulating P retention, especially the percentage $\mathrm{P}$ retention. Therefore, systems receiving event-driven drainage discharge, which reflect on marked variations in HRT, normally show large variability in P retention-potentially shifting from P sinks to P sources. These systems are generally less effective (\%) than systems with more stable hydrological regime.

The review found that $\mathrm{P}$ load correlates positively to mass $\mathrm{P}$ retention due to cumulative $\mathrm{P}$ retention in an area/volume basis and time period. However, increasing P loads may lead to lower percentage $\mathrm{P}$ retention in case these are accompanied by shorter HRTs. The inflow P concentration, on the other hand, normally contributes positively to both mass and percentage P retention. Sedimentation of PP proved to be the main P retention mechanism in CWs and RWs, resulting in the formation of a sediment layer, which ensures long-term $P$ retention and generally represents the largest $P$ pool. Retention of DRP in these systems, however, is limited by the availability of P sorbents, especially in RWs, whose soils are normally enriched with $\mathrm{P}$ from previous agricultural practices. Moreover, non-neutral $\mathrm{pH}$, reducing conditions and low $\mathrm{P}$ concentrations in the water column can inhibit the retention of DRP. Finally, biological uptake of DRP and storage proved to be limited owing to low uptake rates and mineralization of previously assimilated $\mathrm{P}$ during the senescence period. The review also found that retention of DRP in CWs and RWs requires longer HRTs and tends to be more variable in comparison to the retention of PP. Therefore, P retention in these systems is largely affected by the dominant $\mathrm{P}$ form (e.g., DRP or PP), where PP is more easily retained and displays a larger contribution to the overall $\mathrm{P}$ retention. Based on the above, the review recommended determining the $\mathrm{P}$ sorption potential of the soil prior to wetland restoration to assess its capacity for DRP retention.

Filter materials are porous and rich in P sorbents, which promote P sorption reactions, and proved to be potential alternatives in catchments dominated by DRP loads, either as single systems or paired with woodchip bioreactors. The review found that $\mathrm{Fe}$ and Al-based filters are generally superior to those based on $\mathrm{Mg}$ and $\mathrm{Ca}$, as the former allows faster sorption reactions and ensures higher $\mathrm{P}$ stability, achieving higher P retention at shorter HRTs. The review observed, however, a dearth of field studies testing the performance of FMs for P retention, which are essential to ascertain their successful application. Differently from the edge-of-field technologies described above, the review found that VBSs are rarely used in the treatment of agricultural drainage discharge, as the P loads normally bypass these systems in tile-drained catchments and skip the P retention mechanisms. However, these may be used as a complement to design alternatives, where the bypass of $\mathrm{P}$ loads is avoided and retention mechanisms for DRP are enhanced.

The review reported that hydraulic load affects P retention by regulating the HRT and hydraulic efficiency. Thus, percentage P retention is favored under low to moderate hydraulic loads so as to allow sufficient HRT for a significant fraction of the P load to be retained. Hydraulic loads exceeding a critical threshold, on the other hand, favor preferential flow and low level of P mixing across the system, which compromise P retention. The stability of the P retained and long-term P retention, in turn, are largely controlled by the amount of $\mathrm{P}$ sorbents in the system and redox conditions. It was found that drainage discharge enriched with $P$ sorbents can extend the lifetime of the system by supplying it with new sorption sites and ensuring consistent $\mathrm{P}$ sorption capacity, which prevent $\mathrm{P}$ saturation. Moreover, the prevalence of oxidizing conditions supports the stability of Fe-bound P.

A general limitation of edge-of-field technologies is their finite capacity to retain P. Thus, it is expected that the stability of the P retained will decrease in the long-term in response to P saturation, which would compromise P retention. Despite that, the review observed a lack of studies dealing with long-term effects. Likewise, the effect of maintenance operations on extending the lifetime of the systems is poorly reported. The review suggested, however, that operations which remove the excess accumulated P such as sediments removal or periodic harvesting of vegetation in CWs and RWs, or replacing or rejuvenating the spent FM may be beneficial. Moreover, the use of a sedimentation basin prior to the system can markedly reduce the PP load and slow down P saturation. The need for 
large areas, in order to achieve sufficient HRT and acceptable P retention, also limits the application of edge-of-field technologies in agricultural catchments, especially for CWs and RWs. Therefore, cost-efficiency assessments are critical to evaluate the feasibility of edge-of-field technologies for $\mathrm{P}$ retention under specific catchment conditions. The review found, however, that these are poorly reported, and therefore recommends special attention in future research.

The review found that design parameters influence the HRT and hydraulic efficiency of the system. Therefore, attempts to enhance P retention may focus on properly designing the system according to local catchment conditions so as to achieve acceptable P retention. This can include appropriate sizing for sufficient HRT and configuration (e.g., use of a sedimentation basin and pairing of different systems) to achieve acceptable retention of both PP and DRP. In the case of filters, this also includes the material used and its mass. In this context, simulation and modelling of design parameters may contribute to optimize the design and performance. Ultimately, this approach has a great potential to improve the cost-efficiency of edge-of-field technologies for P retention.

Funding: This research received no external funding.

Conflicts of Interest: The author declares no conflicts of interest.

\section{References}

1. Ulén, B.; Bechmann, M.; Fölster, J.; Jarvie, H.P.; Tunney, H. Agriculture as a phosphorus source for eutrophication in the north-west European countries, Norway, Sweden, United Kingdom and Ireland: A review. Soil Use Manag. 2007, 23, 5-15. [CrossRef]

2. Withers, P.J.A.; Haygarth, P.M. Agriculture, phosphorus and eutrophication: A European perspective. Soil Use Manag. 2007, 23, 1-4. [CrossRef]

3. Bechmann, M.; Stålnacke, P. Effect of policy-induced measures on suspended sediments and total phosphorus concentrations from three Norwegian agricultural catchments. Sci. Total Environ. 2005, 304, 238-250. [CrossRef]

4. Sharpley, A.N.; McDowell, R.W.; Kleinman, P.J.A. Phosphorus loss from land to water: Integrating agricultural and environmental management. Plant Soil 2001, 237, 287-307. [CrossRef]

5. Sundareshwar, P.V.; Morris, J.T.; Koepfler, E.K.; Fornwalt, B. Phosphorus limitation of coastal ecosystem processes. Science 2003, 299, 563-565. [CrossRef]

6. Foy, R.H. The return of the phosphorus paradigm: Agricultural phosphorus and eutrophication. In Phosphorus: Agriculture and the Environment; Sims, J.T., Sharpley, A.N., Eds.; American Society of Agronomy Monograph No. 46: Madison, WI, USA, 2005; pp. 911-939.

7. Correll, D.L. The Role of Phosphorus in the Eutrophication of Receiving Waters: A Review. J. Environ. Qual. 1998, 27, 261-266. [CrossRef]

8. Schindler, D.W. Evolution of phosphorus limitation in lakes. Science 1977, 195, 260-262. [CrossRef]

9. Strock, J.S.; Kleinman, P.J.A.; King, K.W.; Delgado, J.A. Drainage water management for water quality protection. J. Soil Water Conserv. 2010, 65, 131A-136A. [CrossRef]

10. Sims, J.T.; Simard, R.R.; Joern, B.C. Phosphorus Loss in Agricultural Drainage: Historical Perspective and Current Research. J. Environ. Qual. 1998, 27, 277-293. [CrossRef]

11. Sharpley, A.N.; Withers, P.J.A. The environmentally-sound management of agricultural phosphorus. Fertil. Res. 1994, 39, 133-146. [CrossRef]

12. Blicher-Mathiesen, G.; Rasmussen, A.; Rolighed, J.; Andersen, H.E.; Carstensen, M.V.; Jensen, P.G.; Wienke, J.; Hansen, B.; Thorling, L. Landovervågningsoplande 2015; NOVANA; Videnskabelig rapport fra DCE—Nationalt Center for Miljø og Energi nr. 205; Aarhus Universitet, DCE-Nationalt Center for Miljø og Energi: Roskilde, Denmark, 2016; 167p.

13. Gelbrecht, J.; Lengsfeld, H.; Pöthig, R.; Opitz, D. Temporal and spatial variation of phosphorus input, retention and loss in a small catchment of NE Germany. J. Hydrol. 2005, 304, 151-165. [CrossRef]

14. Ruark, M.; Madison, A.; Cooley, E.; Stuntebeck, T.; Komiskey, M. Phosphorus loss from tile drains: Should we be concerned? In Proceedings of the Wisconsin Crop Management Conference, University of Wisconsin, Madison, WI, USA, 10-12 January 2012. 
15. King, K.W.; Williams, M.R.; Macrae, M.L.; Fausey, N.R.; Frankenberger, J.; Smith, D.R.; Kleinman, P.J.A.; Brown, L.C. Phosphorus Transport in Agricultural Subsurface Drainage: A Review. J. Environ. Qual. 2015, 44, 467-485. [CrossRef] [PubMed]

16. Johansson, G.; Gustafson, A. Observation Fields on Arable Land; Technical Report; Division of Water Quality Management: Trenton, NJ, USA, 2005.

17. Takeno, N. Atlas of Eh-pH Diagrams: Intercomparison of Thermodynamic Databases; Geological Survey of Japan Open File Report No. 419; National Institute of Advanced Industrial Science and Technology, Research Center for Deep Geological Environments: Tsukuba, Tokyo, 2005.

18. Scalenghe, R.; Edwards, A.C.; Marsan, F.A.; Barberis, E. The effect of reducing conditions on the solubility of phosphorus in a diverse range of European agricultural soils. Eur. J. Soil Sci. 2002, 53, 439-447. [CrossRef]

19. Grant, R.; Laubel, A.; Kronvang, B.; Andersen, H.E.; Svendsen, L.M.; Fuglsang, A. Loss of dissolved and particulate phosphorus from arable catchments by subsurface drainage. Water Res. 1996, 30, 2633-2642. [CrossRef]

20. Mcdowell, R.W.; Sharpley, A.N. Approximating Phosphorus Release from Soils to Surface Runoff and Subsurface Drainage. J. Environ. Qual. 2001, 30, 508-520. [CrossRef]

21. Heckrath, G.; Brookes, P.C.; Poulton, P.R.; Goulding, K.W.T. Phosphorus Leaching from Soils Containing Different Phosphorus Concentrations in the Broadbalk Experiment. J. Environ. Qual. 1995, 24, 904. [CrossRef]

22. McDowell, R.W.; Sharpley, A.N.; Brookes, P.A.; Poulton, P. Relationship between soil test phosphorus and phosphorus release to solution. Soil Sci. 2001, 166, 137-149. [CrossRef]

23. Heiberg, L.; Pedersen, T.V.; Jensen, H.S.; Kjaergaard, C.; Hansen, H.C.B. A Comparative Study of Phosphate Sorption in Lowland Soils under Oxic and Anoxic Conditions. J. Environ. Qual. 2010, 39, 734-743. [CrossRef]

24. Ulén, B. Size and settling velocities of phosphorus-containing particles in water from agricultural drains. Water Air Soil Pollut. 2004, 157, 331-343. [CrossRef]

25. Gentry, L.E.; David, M.B.; Royer, T.V.; Mitchell, C.A.; Starks, K.M. Phosphorus Transport Pathways to Streams in Tile-Drained Agricultural Watersheds. J. Environ. Qual. 2007, 36, 408-415. [CrossRef]

26. Kronvang, B.; Laubel, A.; Grant, R. Suspended sediment and particulate phosphorus transport and delivery pathways in an arable catchment, Gelbaek stream, Denmark. Hydrol. Process. 1997, 11, 627-642. [CrossRef]

27. Steegen, A.; Govers, G.; Takken, I.; Nachtergaele, J.; Poesen, J.; Merckx, R. Factors Controlling Sediment and Phosphorus Export from Two Belgian Agricultural Catchments. J. Environ. Qual. 2001, 30, 1249-1258. [CrossRef] [PubMed]

28. Stone, M.; Mudroch, A. The effect of particle size, chemistry and mineralogy of river sediments on phosphate adsorption. Environ. Technol. Lett. 1989, 10, 501-510. [CrossRef]

29. Eastman, M.; Gollamudi, A.; Stampfli, N.; Madramootoo, C.A.; Sarangi, A. Comparative evaluation of phosphorus losses from subsurface and naturally drained agricultural fields in the Pike River watershed of Quebec, Canada. Agric. Water Manag. 2010, 97, 596-604. [CrossRef]

30. Beauchemin, S.; Simard, R.R.; Cluis, D. Forms and Concentration of Phosphorus in Drainage Water of Twenty-Seven Tile-Drained Soils. J. Environ. Qual. 1998, 27, 721-728. [CrossRef]

31. Syers, J.K.; Johnston, A.E.; Curtin, D. Efficiency of Soil and Fertilizer Phosphorus Use. Reconciling Changing Concepts of Soil Phosphorous Behaviour with Agronomic Information; FAO: Rome, Italy, 2008.

32. Bergström, L.; Kirchmann, H.; Djodjic, F.; Kyllmar, K.; Ulén, B.; Liu, J.; Andersson, H.; Aronsson, H.; Börjesson, G.; Kynkäänniemi, P.; et al. Turnover and Losses of Phosphorus in Swedish Agricultural Soils: Long-Term Changes, Leaching Trends, and Mitigation Measures. J. Environ. Qual. 2015, 44, 512-523. [CrossRef]

33. Andreini, M.S.; Steenhuis, T.S. Preferential paths of flow under conventional and conservation tillage. Geoderma 1990, 46, 85-102. [CrossRef]

34. Gaynor, J.D.; Findlay, W.I. Soil and Phosphorus Loss from Conservation and Conventional Tillage in Corn Production. J. Environ. Qual. 1995, 24, 734-741. [CrossRef]

35. Kleinman, P.J.; Sharpley, A.N.; Saporito, L.S.; Buda, A.R.; Bryant, R.B. Application of manure to no-till soils: Phosphorus losses by sub-surface and surface pathways. Nutr. Cycl. Agroecosyst. 2009, 84, $215-227$. [CrossRef]

36. Lemunyon, J. SERA-17: Innovative Solutions to Minimize Phosphorus Losses from Agriculture. Cover Crops. Available online: https://sera17.org/ (accessed on 12 May 2019). 
37. Kleinman, P.J.; Smith, D.R.; Bolster, C.H.; Easton, Z. M Phosphorus Fate, Management, and Modeling in Artificially Drained Systems. J. Environ. Qual. 2015, 44, 460-466. [CrossRef]

38. Schoumans, O.F.; Van den Berg, R.; Beusen, A.H.W.; Van den Born, G.J.; Renaud, L.; Roelsma, J.; Gronendijk, P. Quick Scan of the Impact of Proposed Application Standards for Animal Manure and Chemical Fertilisers on Nutrient Losses to Groundwater and Surface Waters; Rep. 730.6; Alterra: Wageningen, The Netherlands, 2004. (In Dutch)

39. Djodjic, F.; Bergström, L.; Ulén, B. Phosphorus losses from a structured clay soil in relation to tillage practices. Soil Use Manag. 2002, 18, 79-83. [CrossRef]

40. Peron, H.; Hueckel, T.; Laloui, L.; Hu, L.B. Fundamentals of desiccation cracking of finegrained soils: Experimental characterisation and mechanisms identification. Can. Geotech. J. 2009, 46, 1177-1201. [CrossRef]

41. Liu, J.; Ulén, B.; Bergkvist, G.; Aronsson, H. Freezing-thawing effects on phosphorus leaching from catch crops. Nutr. Cycl. Agroecosyst. 2014, 99, 17-30. [CrossRef]

42. Liu, J.; Khalaf, R.; Ulén, B.; Bergkvist, G. Potential phosphorus release from catch crop shoots and roots after freezing-thawing. Plant Soil 2013, 371, 543-557. [CrossRef]

43. Ulén, B. Episodic precipitation and discharge events and their influence on losses of phosphorus and nitrogen from tile-drained arable fields. Swed. J. Agric. Res. 1995, 25, 25-31.

44. Svanbäck, A.; Ulén, B.; Etana, A.; Bergström, L.; Kleinman, P.J.A.; Mattsson, L. Influence of soil phosphorus and manure on phosphorus leaching in Swedish topsoils. Nutr. Cycl. Agroecosyst. 2013, 96, 133-147. [CrossRef]

45. Haygarth, P.M.; Chapman, P.J.; Jarvis, S.C.; Smith, R.V. Phosphorus budgets for two contrasting grassland farming systems in the UK. Soil Use Manag. 1998, 14, 160-167. [CrossRef]

46. Valero, C.S.; Madramootoo, C.A.; Stämpfli, N. Water table management impacts on phosphorus loads in tile drainage. Agric. Water Manag. 2007, 89, 71-80. [CrossRef]

47. Bryant, R.B.; Buda, A.R.; Kleinman, P.J.A.; Church, C.D.; Saporito, L.S.; Folmar, G.J.; Bose, S.; Allen, A.L. Using Flue Gas Desulfurization Gypsum to Remove Dissolved Phosphorus from Agricultural Drainage Waters. J. Environ. Qual. 2012, 41, 664-671. [CrossRef]

48. Schoumans, O.F.; Kruijne, R.; Van der Molen, D.T. Methods to reduce phosphorus leaching from phosphate saturated soils. Landschap 1995, 12, 63-73. (In Dutch)

49. McDowell, R.W.; Sharpley, A.N.; Bourke, W. Treatment of Drainage Water with Industrial By-Products to Prevent Phosphorus Loss from Tile-Drained Land. J. Environ. Qual. 2008, 37, 1575-1582. [CrossRef] [PubMed]

50. Gburek, W.J.; Sharpley, A.N. Hydrologic Controls on Phosphorus Loss from Upland Agricultural Watersheds. J. Environ. Qual. 1998, 27, 267-277. [CrossRef]

51. Sharpley, A.N.; Bergström, L.; Aronsson, H.; Bechmann, M.; Bolster, C.H.; Börling, K.; Djodjic, F.; Jarvie, H.P.; Schoumans, O.F.; Stamm, C.; et al. Future agriculture with minimized phosphorus losses to waters: Research needs and direction. Ambio 2015, 44, 163-179. [CrossRef] [PubMed]

52. Tanner, C.C.; Nguyen, M.L.; Sukias, J.P.S. Nutrient removal by a constructed wetland treating subsurface drainage from grazed dairy pasture. Agric. Ecosyst. Environ. 2005, 105, 145-162. [CrossRef]

53. Thiere, G.; Milenkovski, S.; Lindgren, P.-E.; Sahlén, G.; Berglund, O.; Weisner, S.E.B. Wetland creation in agricultural landscapes: Biodiversity benefits on local and regional scales. Biol. Conserv. 2009, 142, 964-973. [CrossRef]

54. Kovacic, D.A.; David, M.B.; Gentry, L.E.; Starks, K.M.; Cooke, R.A. Effectiveness of Constructed Wetlands in Reducing Nitrogen and Phosphorus Export from Agricultural Tile Drainage. J. Environ. Qual. 2000, 29, 1262-1274. [CrossRef]

55. De Laney, T.A. Benefits to downstream flood attenuation and water quality as a result of constructed wetlands in agricultural landscapes. J. Soil Water Conserv. 1995, 50, 620-626.

56. Verhoeven, J.T.A.; Arheimer, B.; Yin, C.; Hefting, M.M. Regional and global concerns over wetlands and water quality. Trends Ecol. Evol. 2006, 21, 96-103. [CrossRef] [PubMed]

57. Keddy, P.A. Wetland Ecology: Principles and Conservation, 2nd ed.; Cambridge University Press: New York, NY, USA, 2010.

58. Reddy, K.R.; Kadlec, R.H.; Flaig, E.; Gale, P.M. Phosphorus Retention in Streams and Wetlands: A Review. Crit. Rev. Environ. Sci. Technol. 1999, 29, 83-146. [CrossRef] 
59. Décamps, H.; Naiman, R.J.; McClain, M.E. Riparian Zones. In River Ecosystem Ecology: A Global Perspective; Likens, G.E., Ed.; Academic Press: San Diego, CA, USA, 2009; pp. 182-189.

60. Blann, K.L.; Anderson, J.L.; Sands, G.R.; Vondracek, B. Effects of Agricultural Drainage on Aquatic Ecosystems: A Review. Crit. Rev. Environ. Sci. Technol. 2009, 39, 909-1001. [CrossRef]

61. McCorvie, M.R.; Lant, C.L. Drainage district formation and the loss of Midwestern wetlands, 1850-1930. Agric. Hist. 1993, 67, 13-39.

62. Stromberg, J.C. Restoration of riparian vegetation in the south-western United States: Importance of flow regimes and fluvial dynamism. J. Arid. Environ. 2001, 49, 17-34. [CrossRef]

63. Nair, V.D.; Graetz, D.A. Phosphorus Saturation in Spodosols Impacted by Manure. J. Environ. Qual. 2002, 31, 1279-1285. [CrossRef] [PubMed]

64. Allen, B.L.; Mallarino, A.P. Relationships between Extractable Soil Phosphorus and Phosphorus Saturation after Long-Term Fertilizer or Manure Application. Soil Sci. Soc. Am. J. 2006, 70, 454-463. [CrossRef]

65. Börling, K.; Otabbonga, E.; Barberis, E. Soil Variables for Predicting Potential Phosphorus Release in Swedish Noncalcareous Soils. J. Environ. Qual. 2004, 33, 99-106. [CrossRef] [PubMed]

66. Wu, H.; Zhang, J.; Ngo, H.H.; Guo, W.; Hub, Z.; Liang, S.; Fan, J.; Liu, H. A review on the sustainability of constructed wetlands for wastewater treatment: Design and operation. Bioresour. Technol. 2015, 175, 594-601. [CrossRef]

67. Kadlec, R.H.; Wallace, S.D. Treatment Wetlands, 2nd ed.; CRC Press Taylor \& Francis Group: Boca Raton, FL, USA, 2008.

68. Braskerud, B.C. Factors affecting phosphorus retention in small constructed wetlands treating agricultural non-point source pollution. Ecol. Eng. 2002, 19, 41-61. [CrossRef]

69. Johannesson, K.M.; Andersson, J.L.; Tonderski, K.S. Efficiency of a constructed wetland for retention of sediment-associated phosphorus. Hydrobiologia 2011, 674, 179-190. [CrossRef]

70. Johannesson, K.M.; Kynkäänniemi, P.; Ulén, B.; Weisner, S.E.B.; Tonderski, K.S. Phosphorus and particle retention in constructed wetlands-A catchment comparison. Ecol. Eng. 2015, 80, 20-31. [CrossRef]

71. Kynkäänniemi, P.; Ulén, B.; Torstensson, G.; Tonderski, K.S. Phosphorus Retention in a Newly Constructed Wetland Receiving Agricultural Tile Drainage Water. J. Environ. Qual. 2013, 42, 596-605. [CrossRef]

72. Maynard, J.J.; Geen, A.T.O.; Dahlgren, R.A.; Davis, C. Bioavailability and Fate of Phosphorus in Constructed Wetlands Receiving Agricultural Runoff in the San Joaquin Valley, California. J. Environ. Qual. 2009, 38, 360-372. [CrossRef]

73. Mendes, L.R.D.; Tonderski, K.; Iversen, B.V.; Kjaergaard, C. Phosphorus retention in surface-flow constructed wetlands targeting agricultural drainage water. Ecol. Eng. 2018, 120, 94-103. [CrossRef]

74. Kroeger, A.C.; Madramootoo, C.A.; Enright, P.; Laflamme, C. Efficiency of a small constructed wetland in southern Québec for treatment of agricultural runoff waters. In Proceedings of the Wastewater Biosolids Sustainability: Technical, Managerial, and Public Synergy, Moncton, NB, Canada, 24-27 June 2007; pp. 1057-1062.

75. Tanner, C.C.; Sukias, J.P.S. Multiyear nutrient removal performance of three constructed wetlands intercepting tile drain flows from grazed pastures. J. Environ. Qual. 2011, 40, 620-633. [CrossRef]

76. Reinhardt, M.; Gächter, R.; Wehrli, B.; Müller, B. Phosphorus retention in small constructed wetlands treating agricultural drainage water. J. Environ. Qual. 2005, 34, 1251-1259. [CrossRef] [PubMed]

77. Crumpton, W.G.; Kovacic, D.A.; Hey, D.L.; Kostel, J.A. Potential of Restored and Constructed Wetlands to Reduce Nutrient Export from Agricultural Watersheds in the Corn Belt. In Final Report: Gulf Hypoxia and Local Water Quality Concerns Workshop; American Society of Agricultural and Biological Engineers: St. Joseph, MI, USA, 2008; pp. 29-42.

78. DeBusk, T.A.; Grace, K.A.; Dierberg, F.E. Treatment wetlands for removing phosphorus from agricultural drainage water. In Nutrient Management in Agricultural Watersheds: A Wetlands Solution; Dunne, E.J., Reddy, K.R., Carton, O.T., Eds.; Wageningen Academic Publishers: Wageningen, The Netherlands, 2005; pp. 167-178.

79. O'Geen, A.T.; Budd, R.; Gan, J.; Maynard, J.J.; Parikh, S.J.; Dahlgren, R.A. Mitigating Nonpoint Source Pollution in Agriculture with Constructed and Restored Wetlands. Adv. Agron. 2010, 108, 1-76.

80. Mendes, L.R.D.; Tonderski, K.; Kjaergaard, C. Phosphorus accumulation and stability in sediments of surface-flow constructed wetlands. Geoderma 2018, 331, 109-120. [CrossRef] 
81. Hoagland, C.R.; Gentry, L.E.; David, M.B.; Kovacic, D.A. Plant Nutrient Uptake and Biomass Accumulation in a Constructed Wetland. J. Freshw. Ecol. 2001, 16, 527-540. [CrossRef]

82. Gu, B.; Dreschel, T. Effects of plant community and phosphorus loading rate on constructed wetland performance in Florida, USA. Wetlands 2008, 28, 81-91. [CrossRef]

83. Kao, J.T.; Titus, J.E.; Zhu, W.-X. Differential nitrogen and phosphorus retention by five wetland plant species. Wetlands 2003, 23, 979-987. [CrossRef]

84. Vymazal, J. Emergent plants used in free water surface constructed wetlands: A review. Ecol. Eng. 2013, 61, 582-592. [CrossRef]

85. Pant, H.K.; Reddy, K.R.; Dierberg, F.E. Bioavailability of Organic Phosphorus in a Submerged Aquatic Vegetation-Dominated Treatment Wetland. J. Environ. Qual. 2002, 31, 1748-1756. [CrossRef]

86. Pant, H.K.; Reddy, K.R. Hydrologic influence on stability of organic phosphorus in wetland detritus. J. Environ. Qual. 2001, 30, 668-674. [CrossRef]

87. Dunne, E.J.; Culleton, N.; O’Donovan, G.; Harrington, R.; Daly, K. Phosphorus retention and sorption by constructed wetland soils in Southeast Ireland. Water Res. 2005, 39, 4355-4362. [CrossRef] [PubMed]

88. Lai, D.Y.F. Phosphorus fractions and fluxes in the soils of a free surface flow constructed wetland in Hong Kong. Ecol. Eng. 2014, 73, 73-79. [CrossRef]

89. Braskerud, B.C.; Tonderski, K.S.; Wedding, B.; Bakke, R.; Blankenberg, A.G.; Ulen, B.; Koskiaho, J. Can constructed wetlands reduce the diffuse phosphorus loads to eutrophic water in cold temperate regions? J. Environ. Qual. 2005, 34, 2145-2155. [CrossRef]

90. Braskerud, B.C. The influence of vegetation on sedimentation and resuspension of soil particles in small constructed wetlands. J. Environ. Qual. 2001, 30, 1447-1457. [CrossRef] [PubMed]

91. Braskerud, B.C. Clay particle retention in small constructed wetlands. Water Res. 2003, 37, 3793-3802. [CrossRef]

92. Lavrnić, S.; Braschi, I.; Anconelli, S.; Blasioli, S.; Solimando, D.; Mannini, P.; Toscano, A. Long-Term Monitoring of a Surface Flow Constructed Wetland Treating Agricultural Drainage Water in Northern Italy. Water 2018, 10, 644. [CrossRef]

93. Johannesson, K.M.; Tonderski, K.S.; Ehde, P.M.; Weisner, S.E.B. Temporal phosphorus dynamics affecting retention estimates inagricultural constructed wetlands. Ecol. Eng. 2017, 103, 436-445. [CrossRef]

94. Land, M.; Granéli, W.; Grimvall, A.; Hoffmann, C.C.; Mitsch, W.J.; Tonderski, K.S.; Verhoeven, J.T. How effective are created or restored freshwater wetlands for nitrogen and phosphorus removal? A systematic review. Environ. Evid. 2016, 5, 9. [CrossRef]

95. Geranmayeh, P.; Johannesson, K.M.; Ulén, B.; Tonderski, K.S. Particle deposition, resuspension and phosphorus accumulation in small constructed wetlands. Ambio 2018, 47, 134-145. [CrossRef] [PubMed]

96. Persson, J.; Somes, N.L.G.; Wong, T.H.F. Hydraulic efficiency of constructed wetlands and ponds. Water Sci. Technol. 1999, 40, 291-300. [CrossRef]

97. Dierberg, F.E.; Juston, J.J.; DeBusk, T.A.; Pietro, K.; Gu, B. Relationship between hydraulic efficiency and phosphorus removal in a submerged aquatic vegetation-dominated treatment wetland. Ecol. Eng. 2005, 25, 9-23. [CrossRef]

98. Maynard, J.J.; O'Geen, A.T.; Dahlgren, R.A. Spatial Relationships of Phosphorus Sorption in a Seasonally Saturated Constructed Wetland Soil. Soil Sci. Soc. Am. J. 2009, 73, 1741-1753. [CrossRef]

99. Su, T.-M.; Yang, S.-C.; Shih, S.-S.; Lee, H.-Y. Optimal design for hydraulic efficiency performance of free-water-surface constructed wetlands. Ecol. Eng. 2009, 35, 1200-1207. [CrossRef]

100. Guo, C.; Cui, Y.; Dong, B.; Luo, Y.; Liu, F.; Zhao, S.; Wu, H. Test study of the optimal design for hydraulic performance and treatment performance of free water surface flow constructed wetland. Bioresour. Technol. 2017, 238, 461-471. [CrossRef]

101. Braskerud, B.C. Design considerations for increased sedimentation in small wetlands treating agricultural runoff. Water Sci Technol. 2002, 45, 77-85. [CrossRef]

102. Dierberg, F.E.; DeBusk, T.A. Particulate phosphorus transformations in south Florida stormwater treatment areas used for Everglades protection. Ecol. Eng. 2008, 34, 100-115. [CrossRef]

103. Van der Zee, S.E.A.T.M.; Van Riemsdijk, W.H. Sorption kinetics and transport of phosphate in sandy soil. Geoderma 1986, 38, 293-309. [CrossRef]

104. Zou, Y.; Zhang, L.; Wang, L.; Zhang, S.; Yu, X. Effects of Aeration, Vegetation, and Iron Input on Total P Removal in a Lacustrine Wetland Receiving Agricultural Drainage. Water. 2018, 10, 61. [CrossRef] 
105. Flessa, H. Plant-induced changes in the redox potential of the rhizospheres of the submerged vascular macrophytes Myriophyllum verticillatum L. and Ranunculus circinatus L. Aquat. Bot. 1994, 47, 119-129. [CrossRef]

106. Armstrong, J.; Armstrong, W. Light-enhanced convective throughflow increases oxygenation in rhizomes and rhizosphere of Phragmites australis (Cav.) Trin. ex Steud. New Phytol. 1990, 114, 121-128. [CrossRef]

107. Moore, B.C.; Lafer, J.E.; Funk, W.H. Influence of aquatic macrophytes on phosphorus and sediment porewater chemistry in a freshwater wetland. Aquat. Bot. 1994, 49, 137-148. [CrossRef]

108. White, J.R.; Reddy, K.R.; Moustafa, M.Z. Influence of hydrologic regime and vegetation on phosphorus retention in Everglades stormwater treatment area wetlands. Hydrol. Process. 2004, 18, 343-355. [CrossRef]

109. Olila, O.G.; Reddy, K.R.; Stites, D.L. Influence of draining on soil phosphorus forms and distribution in a constructed wetland. Ecol. Eng. 1997, 9, 157-169. [CrossRef]

110. Ann, Y.; Reddy, K.R.; Delfino, J.J. Influence of chemical amendments on phosphorus immobilization in soils from a constructed wetland. Ecol. Eng. 1999, 14, 157-167. [CrossRef]

111. Ballantine, D.J.; Tanner, C.C. Substrate and filter materials to enhance phosphorus removal in constructed wetlands treating diffuse farm runoff: A review. N. Z. J. Agric. Res. 2010, 53, 71-95. [CrossRef]

112. Li, Y.; Wang, S.; Li, Y.; Kong, F.; Xi, H.; Liu, Y. Corn Straw as a Solid Carbon Source for the Treatment of Agricultural Drainage Water in Horizontal Subsurface Flow Constructed Wetlands. Water 2018, 10, 511. [CrossRef]

113. Vymazal, J. Constructed Wetlands for Wastewater Treatment. Water 2010, 2, 530-549. [CrossRef]

114. Gachango, F.G.; Pedersen, S.M.; Kjaergaard, C. Cost-Effectiveness Analysis of Surface Flow Constructed Wetlands (SFCW) for Nutrient Reduction in Drainage Discharge from Agricultural Fields in Denmark. Environ. Manag. 2015, 56, 1478-1486. [CrossRef]

115. Schoumans, O.F.; Chardon, W.J.; Bechmann, M.E.; Gascuel-Odoux, C.; Hofman, G.; Kronvang, B.; Ulén, B.; Dorioz, J.-M. Mitigation options to reduce phosphorus losses from the agricultural sector and improve surface water quality: A review. Sci. Total Environ. 2014, 468-469, 1255-1266. [CrossRef] [PubMed]

116. Kronvang, B.; Bechmann, M.; Lundekvam, H.; Behrendt, H.; Rubæk, G.H.; Schoumans, O.F.; Syversen, N.; Andersen, H.E.; Hoffmann, C.C. Phosphorus Losses from Agricultural Areas in River Basins: Effects and Uncertainties of Targeted Mitigation Measures. J. Environ. Qual. 2005, 34, 2129-2144. [CrossRef] [PubMed]

117. Hoffmann, C.C.; Kjaergaard, C.; Uusi-Kämppä, J.; Hansen, H.C.B.; Kronvang, B. Phosphorus Retention in Riparian Buffers: Review of Their Efficiency. J. Environ. Qual. 2009, 38, 1942-1955. [CrossRef]

118. Shenker, M.; Seitelbach, S.; Brand, S.; Haim, A.; Litaor, M.I. Redox reactions and phosphorus release in re-flooded soils of an altered wetland. Eur. J. Soil Sci. 2005, 56, 515-525. [CrossRef]

119. Hoffmann, C.C.; Baattrup-Pedersen, A.; Amsinck, S.L.; Clausen, P. Overvågning af Vandmiljøplan II Vådområder 2005; Faglig rapport fra DMU nr. 576; Danmarks Miljøundersøgelser: Silkeborg, Denmark, 2006. (In Danish)

120. Hoffmann, C.C.; Heiberg, L.; Audet, J.; Schønfeldt, B.; Fuglsang, A.; Kronvang, B.; Ovesen, N.B.; Kjaergaard, C.; Hansen, H.C.B.; Jensen, H.S.; et al. Low phosphorus release but high nitrogen removal in two restored riparian wetlands inundated with agricultural drainage water. Ecol. Eng. 2012, 46, 75-87. [CrossRef]

121. Hogan, D.M.; Jordan, T.E.; Walbridge, M.R. Phosphorus retention and soil organic carbon in restored and natural freshwater wetlands. Wetlands 2004, 24, 573-585. [CrossRef]

122. Woltemade, C.J. Ability of restored wetlands to reduce nitrogen and phosphorus concentrations in agricultural drainage water. J. Soil Water Conserv. 2000, 55, 303-309.

123. Liikanen, A.; Puustinen, M.; Koskiaho, J.; Väisänen, T.; Martikainen, P.; Hartikainen, H. Phosphorus Removal in a Wetland Constructed on Former Arable Land. J. Environ. Qual. 2004, 33, 1124-1132. [CrossRef]

124. Zedler, J.B. Wetlands at your service: Reducing impacts of agriculture at the watershed scale. Front. Ecol. Environ. 2003, 1, 65-72. [CrossRef]

125. Jordan, T.E.; Whigham, D.F.; Hofmockel, K.H.; Pittek, M.A. Nutrient and Sediment Removal by a Restored Wetland Receiving Agricultural Runoff. J. Environ. Qual. 2003, 32, 1534-1547. [CrossRef]

126. Hickey, M.B.C.; Doran, B. A Review of the Efficiency of Buffer Strips for the Maintenance and Enhancement of Riparian Ecosystems. Water Qual. Res. J. Can. 2004, 39, 311-317. [CrossRef]

127. Muscutt, A.D.; Harris, G.L.; Bailey, S.W.; Davies, D.B. Buffer zones to improve water quality: A review of their potential use in UK agriculture. Agric. Ecosyst. Environ. 1993, 45, 59-77. [CrossRef]

128. Parkyn, S. Review of Riparian Buffer Zone Effectiveness; Technical Paper No 2004/05; Ministry of Agriculture and Forestry: Wellington, New Zealand, 2004. 
129. Osborne, L.L.; Kovacic, D.A. Riparian vegetated buffer strips in water-quality restoration and stream management. Freshw. Biol. 1993, 29, 243-258. [CrossRef]

130. McDowell, R.W.; Biggs, B.J.F.; Sharpley, A.N.; Nguyen, L. Connecting phosphorus loss from agricultural landscapes to surface water quality. Chem. Ecol. 2004, 20, 1-40. [CrossRef]

131. Wenger, S. A Review of the Scientific Literature on Riparian Buffer Width, Extent and Vegetation; Office of Public Service and Outreach, Institute of Ecology, University of Georgia: Athens, GA, USA, 1999.

132. Roberts, W.M.; Stutter, M.I.; Haygarth, P.M. Phosphorus Retention and Remobilization in Vegetated Buffer Strips: A Review. J. Environ. Qual. 2012, 41, 389-399. [CrossRef] [PubMed]

133. Uusi-Kämppä, J.; Yläranta, T. Effect of buffer strips on controlling soil erosion and nutrient losses in southern Finland. In Wetlands: Environmental Gradients, Boundaries, and Buffers; Mulamoottil, G., Warner, B.G., McBean, E.A., Eds.; CRC Press, Lewis Publishers: Boca Raton, FL, USA, 1996; pp. 221-235.

134. Helmers, M.J.; Isenhart, T.M.; Dosskey, M.G.; Dabney, S.M.; Strock, J.S. Buffers and Vegetative Filter Strips. In UMRSHNC (Upper Mississippi River Sub-basin Hypoxia Nutrient Committee) Final Report: Gulf Hypoxia and Local Water Quality Concerns Workshop; American Society of Agricultural and Biological Engineers: St. Joseph, MI, USA, 2008; pp. 43-58.

135. Bhattarai, R.; Kalita, P.K.; Patel, M.K. Nutrient transport through a Vegetative Filter Strip with subsurface drainage. J. Environ. Manag. 2009, 90, 1868-1876. [CrossRef]

136. Zak, D.; Kronvang, B.; Carstensen, M.V.; Hoffmann, C.C.; Kjeldgaard, A.; Larsen, S.E.; Audet, J.; Egemose, S.; Jorgensen, C.A.; Feuerbach, P.; et al. Nitrogen and Phosphorus Removal from Agricultural Runoff in Integrated Buffer Zones. Environ. Sci. Technol. 2018, 52, 6508-6517. [CrossRef]

137. Penn, C.; McGrath, J.; Bowen, J.; Wilson, S. Phosphorus removal structures: A management option for legacy phosphorus. J. Soil Water Conserv. 2014, 69, 51A-56A. [CrossRef]

138. Penn, C.J.; Bryant, R.B.; Kleinman, P.J.A.; Allen, A.L. Removing dissolved phosphorus from drainage ditch water with phosphorus sorbing materials. J. Soil Water Conserv. 2007, 62, 269-276.

139. Lyngsie, G.; Borggaard, O.K.; Hansen, H.C.B. A three-step test of phosphate sorption efficiency of potential agricultural drainage filter materials. Water Res. 2014, 51, 256-265. [CrossRef]

140. Canga, E.; Heckrath, G.J.; Kjaergaard, C. Agricultural Drainage Filters. II. Phosphorus Retention and Release at Different Flow Rates. Water Air Soil Pollut. 2016, 227, 276-288. [CrossRef]

141. Lyngsie, G.; Penn, C.J.; Hansen, H.C.B.; Borggaard, O.K. Phosphate sorption by three potential filter materials as assessed by isothermal titration calorimetry. J. Environ. Manag. 2014, 143, 26-33. [CrossRef] [PubMed]

142. Allred, B.J.; Racharaks, R. Laboratory Comparison of Four Iron-Based Filter Materials for Drainage Water Phosphate Treatment. Water Environ. Res. 2014, 86, 852-862. [CrossRef] [PubMed]

143. Allred, B.J. Laboratory evaluation of porous iron composite for agricultural drainage water filter treatment. Trans. ASABE 2012, 55, 1683-1697. [CrossRef]

144. Allred, B.J. Laboratory batch test evaluation of five filter materials for removal of nutrients and pesticides from drainage waters. Trans ASABE 2010, 53, 39-54. [CrossRef]

145. King, K.W.; McDonald, J.; Moore, J.F.; Agrawal, S.G.; Fischer, E.N.; Balogh, J.C. Nutrient and pesticide removal from laboratory-simulated tile drainage discharge. Trans. ASABE 2010, 53, 769-777. [CrossRef]

146. Kirkkala, T.; Ventelä, A.-M.; Tarvainen, M. Fosfilt filters in an agricultural catchment: A long-term field-scale experiment. Agric. Food Sci. 2012, 21, 237-246. [CrossRef]

147. Gottschall, N.; Edwards, M.; Craiovan, E.; Frey, S.K.; Sunohara, M.; Ball, B.; Zoski, E.; Topp, E.; Khana, I.; Clark, I.D.; et al. Amending woodchip bioreactors with water treatment plant residuals to treat nitrogen, phosphorus, and veterinary antibiotic compounds in tile drainage. Ecol. Eng. 2016, 95, 852-864. [CrossRef]

148. Carstensen, M.V.; Larsen, S.E.; Kjærgaard, C.; Hoffmann, C.C. Reducing adverse side effects by seasonally lowering nitrate removal in subsurface flow constructed wetlands. J. Environ. Manag. 2019, 240, 190-197. [CrossRef]

149. Christianson, L.E.; Lepine, C.; Sibrell, P.L.; Penn, C.; Summerfelt, S.T. Denitrifying woodchip bioreactor and phosphorus filter pairing to minimize pollution swapping. Water Res. 2017, 121, 129-139. [CrossRef]

150. Goodwin, G.E.; Bhattarai, R.; Cooke, R. Synergism in nitrate and orthophosphate removal in subsurface bioreactors. Ecol. Eng. 2015, 84, 559-568. [CrossRef]

151. Hua, G.; Salo, M.W.; Schmit, C.G.; Hay, C.H. Nitrate and phosphate removal from agricultural subsurface drainage using laboratory woodchip bioreactors and recycled steel byproduct filters. Water Res. 2016, 102, 180-189. [CrossRef] [PubMed] 
152. Thapa, U. Evaluation of Woodchip Bioreactors and Phosphorus Adsorption Media for Nutrient Removal from Subsurface Drainage Water; South Dakota State University: Brookings, SD, USA, 2017.

153. Stoner, D.; Penn, C.; McGrath, J.; Warren, J. Phosphorus Removal with By-Products in a Flow-Through Setting. J. Environ. Qual. 2012, 41, 654-663. [CrossRef] [PubMed]

154. Penn, C.; Chagas, I.; Klimeski, A.; Lyngsie, G. A Review of Phosphorus Removal Structures: How to Assess and Compare Their Performance. Water 2017, 9, 583. [CrossRef]

155. Buda, A.R.; Koopmans, G.F.; Bryant, R.B.; Chardon, W.J. Emerging Technologies for Removing Nonpoint Phosphorus from Surface Water and Groundwater: Introduction. J. Environ. Qual. 2012, 41, 621-627. [CrossRef] [PubMed]

156. Lyngsie, G.; Penn, C.J.; Pedersen, H.L.; Borggaard, O.K.; Hansen, H.C.B. Modelling of phosphate retention by Ca- and Fe-rich filter materials under flow-through conditions. Ecol. Eng. 2015, 75, 93-102. [CrossRef]

(C) 2020 by the author. Licensee MDPI, Basel, Switzerland. This article is an open access article distributed under the terms and conditions of the Creative Commons Attribution (CC BY) license (http://creativecommons.org/licenses/by/4.0/). 